\title{
Nuclear detection of Y-box protein-I (YB-I) closely associates with progesterone receptor negativity and is a strong adverse survival factor in human breast cancer
}

\author{
Edgar Dahl*1, Abdelaziz En-Nia ${ }^{2}$, Frank Wiesmann ${ }^{1}$, Renate Krings ${ }^{3}$, \\ Sonja Djudjaj ${ }^{2}$, Elisabeth Breuer ${ }^{1}$, Thomas Fuchs ${ }^{4}$, Peter J Wild ${ }^{5}$, \\ Arndt Hartmann ${ }^{6}$, Sandra E Dunn ${ }^{7}$ and Peter R Mertens*2
}

\begin{abstract}
Address: ${ }^{1}$ Molecular Oncology Group, Institute of Pathology, Medical Faculty, RWTH Aachen University, Aachen, Germany, ${ }^{2}$ Department of Nephrology and Hypertension, Otto-von-Guericke-University Magdeburg, Magdeburg, Germany, ${ }^{3}$ Department of Nephrology and Immunology, Medical Faculty, RWTH Aachen University, Aachen, Germany, ${ }^{4}$ Department of Computer Science, ETH Zurich, Zurich, Switzerland, 5 Institute of Surgical Pathology, University Hospital Zurich, Zurich, Switzerland, ${ }^{6}$ Department of Pathology, University of Erlangen, Germany and ${ }^{7}$ Laboratory for Oncogenomic Research, Department of Pediatrics, Child and Family Research Institute, University of British Columbia, Vancouver, British Columbia, Canada

Email: Edgar Dahl* - edahl@ukaachen.de; Abdelaziz En-Nia - aen-nia@ukaachen.de; Frank Wiesmann - fwiesmann@ukaachen.de; Renate Krings - rkrings@ukaachen.de; Sonja Djudjaj - sonja.djudjaj@med.ovgu.dE; Elisabeth Breuer - ebreuer@ukaachen.de; Thomas Fuchs - thomas.fuchs@inf.ethz.ch; Peter J Wild - peter.wild@cell.biol.ethz.ch; Arndt Hartmann - arndt.hartmann@uk-erlangen.de; Sandra E Dunn - sedunn@interchange.ubc.ca; Peter R Mertens* - peter.mertens@med.ovgu.de

${ }^{*}$ Corresponding authors
\end{abstract}

Published: 24 November 2009

BMC Cancer 2009, 9:4I0 doi:I0.|| 86/|47|-2407-9-410
Received: 28 February 2009

Accepted: 24 November 2009

This article is available from: http://www.biomedcentral.com/I47I-2407/9/4 I0

(C) 2009 Dahl et al; licensee BioMed Central Ltd.

This is an Open Access article distributed under the terms of the Creative Commons Attribution License (http://creativecommons.org/licenses/by/2.0), which permits unrestricted use, distribution, and reproduction in any medium, provided the original work is properly cited.

\begin{abstract}
Background: Y-box binding protein-I (YB-I) is the prototypic member of the cold shock protein family that fulfills numerous cellular functions. In the nucleus YB-I protein orchestrates transcription of proliferation-related genes, whereas in the cytoplasm it associates with mRNA and directs translation. In human tumor entities, such as breast, lung and prostate cancer, cellular YBI expression indicates poor clinical outcome, suggesting that YB-I is an attractive marker to predict patients' prognosis and, potentially, is suitable to individualize treatment protocols. Given these predictive qualities of YB-I detection we sought to establish a highly specific monoclonal antibody (Mab) for diagnostic testing and its characterization towards outcome prediction (relapse-free and overall survival).
\end{abstract}

Methods: Hybridoma cell generation was carried out with recombinant YB-I protein as immunogen and Mab characterization was performed using immunoblotting and ELISA with recombinant and tagged YB-I proteins, as well as immunohistochemistry of healthy and breast cancer specimens. Breast tumor tissue array staining results were analyzed for correlations with receptor expression and outcome parameters.

Results: YB-I-specific Mab F-E2G5 associates with conformational binding epitopes mapping to two domains within the $\mathrm{N}$-terminal half of the protein and detects nuclear YB-I protein by immunohistochemistry in paraffin-embedded breast cancer tissues. Prognostic evaluation of Mab FE2G5 was performed by immunohistochemistry of a human breast cancer tissue microarray comprising 179 invasive breast cancers, 8 ductal carcinoma in situ and 37 normal breast tissue samples. Nuclear YB-I detection in human breast cancer cells was associated with poor overall 
survival ( $p=0.0046$ ). We observed a close correlation between nuclear YB-I detection and absence of progesterone receptor expression $(p=0.002)$, indicating that nuclear $Y B-I$ detection marks a specific subgroup of breast cancer. Likely due to limitation of sample size Cox regression models failed to demonstrate significance for nuclear YB-I detection as independent prognostic marker.

Conclusion: Monoclonal YB-I antibody F-E2G5 should be of great value for prospective studies to validate $Y B-I$ as a novel biomarker suitable to optimize breast cancer treatment.

\section{Background}

Since the seminal description of Janz et al. [1] that high YB-1 expression levels in breast cancer and surrounding tissues are indicative for poor outcome, follow-up studies have extended these findings to larger cohorts and other cancer entities, including non-small cell lung cancer [2], ovarian cancer [3], prostate cancer [4], and synovial sarcoma [5]. A recent study confirmed the unfavorable outcome of patients with YB-1 expression in breast cancer tissue with a large cohort of 4049 cases over an observation period of 20 years, which reached statistical significance in nearly all subgroups [6]. Furthermore, Bargou et al. [7] reported that nuclear localization of YB-1 was associated with P-glycoprotein expression in human primary breast cancers, other studies have shown a co-expression of YB-1 and P-glycoprotein in osteo- and synovial sarcoma as well as breast, ovarian and prostate cancer $[3,5,8$ $11]$.

Cold-shock proteins like the Y-box binding (YB) protein fulfill pleiotropic functions, e.g. regulation of target genes, (pre-)mRNA splicing and translation [12-16]. YB-1 is a multifunctional protein with fascinating roles in cell biology. First and utmost, YB-1 serves multiple roles in gene transcription with numerous target genes involved in DNA replication and proliferation [17-22]. Overexpression of YB-1 via a transgene in a mouse model induced the development of breast cancers of many histological types [23], suggesting that YB-1 is oncogenic. Reports confirm the relevance of YB-1 expression for EGF-independent breast cancer cell growth [24]. Following its original cloning as binding activity of the EGF receptor promoter [25], Dunn et al. recently reported that YB-1 is a strong transstimulator of EGF receptor expression in breast cancer cells [26].

A predominant nuclear localization of YB-1 protein goes along with intrinsic expression of putative oncogenes $[1,4,24,27]$, response to oxidative stress and coordination of DNA excision repair [28]. On the other hand, there is evidence for a prominent role of YB-1 as RNA-binding molecule and constituent of cytoplasmic major messenger ribonucleoprotein particles (in this context denoted p50) $[29,30]$. Studies addressing the question what regulates YB-1 expression, its subcellular localization and potential protein modifications have shed some light on underlying mechanisms. The transcription of YB-1 is upregulated by basic helix-loop-helix transcription factor Twist [31]. Twist itself is an immediate target of signal tranducers and activator of transcription (STAT)-3, which may be activated by epidermal growth factor receptor signaling [32]. Knockdown of YB-1 completely abrogated the proliferative effect of Twist, emphasizing the fundamental role that YB-1 plays for the EGF receptor axis. Furthermore, serine 102 of YB-1 protein is a direct target of protein kinases B (AKT) and RSK [33], both of which are signaling cascades involved in cell transformation, proliferation and anchorage-independent growth $[17,27,34]$.

A general evaluation of YB-1 expression in breast cancer patients is limited due to lack of a suitable antibody of unrestricted quantity and defined quality, preferably monoclonal. This could potentially allow to diversify their relative risk profile and chemotherapy sensitivity $[7,35]$. Furthermore, most polyclonal antibodies, like the ones used for breast cancer tissue by Janz et al. [1] and Habibi et al. [6], predominantly detect YB-1 in the cytoplasm, whereas YB-1 protein activities relating to chromosomal instability and gene regulation must take place within the nuclear compartment [36].

In the following we present data on a newly established monoclonal YB-1 antibody that is characterized as suitable for immunohistochemistry in paraffin-embedded tissue. The expression of YB- 1 by means of this antibody was analyzed by immunohistochemistry in a cohort of breast cancer specimens. For all tumour specimens analyzed, full histopathological and clinical follow-up data were available, allowing uni- and multivariate analyses of nuclear YB1 expression in correlation to well-established factors of breast cancer prognosis (grade, nodal status, HER2, estrogen receptor (ER) status, progesterone receptor (PR) status). Thereby we characterized the Mab as a novel tool that can be used in breast cancer prognosis and therapy stratification.

\section{Methods \\ Mab generation}

Mouse work was in full compliance with the guidelines for animal care and was approved by the animal care com- 
mittee from the government. Female BALB/c mice were immunized by intraperitoneal and intravenous injection of $100 \mu \mathrm{g}$ recombinant YB-1 full-length protein emulsified in equal volume of Freund's adjuvant (Gibco-BRL life technologies, Karlsruhe, Germany) followed by a booster injection six weeks later containing $10 \mu \mathrm{g}$ of antigen in Freund's adjuvant. The response was assessed by dot blot assay with recombinant YB-1 protein. Three days after the last booster injection, spleen cells were obtained and fused with X63-Ag/653 (BALB/c) mouse myeloma cells and propagated according to standard procedures. The fused cells were resuspended in DMEM medium (Gibco BRL life technologies) supplemented with $10 \%$ bovine calf serum, $100 \mathrm{U} / \mathrm{ml}$ penicillin, $100 \mu \mathrm{g} / \mathrm{ml}$ streptomycin, $50 \mu \mathrm{M}$ hypoxanthine, $160 \mu \mathrm{M}$ thymidine, and $400 \mathrm{nM}$ aminopterin. Aliquots of the cell suspension $(100 \mu \mathrm{l})$ were dispensed into 96-well plates and incubated at $37^{\circ} \mathrm{C} / 5 \% \mathrm{CO}_{2}$. Every week the medium was replaced with fresh selection medium supplemented with recombinant interleukin-6 $(100 \mathrm{U} / \mathrm{ml})$. After two weeks the medium was replaced by HT-medium (DMEM medium (Gibco BRL life technologies) supplemented with $10 \%$ bovine calf serum, $100 \mathrm{U} / \mathrm{ml}$ penicillin, $100 \mu \mathrm{g} / \mathrm{ml}$ streptomycin, $100 \mu \mathrm{M}$ hypoxanthine and $160 \mu \mathrm{M}$ thymidine and another week later cells were cultured in standard DMEM medium (4500 mg/l D-Glucose supplemented with GlutaMax (Gibco BRL life technologies) with $10 \%$ bovine calf serum, $100 \mathrm{U} / \mathrm{ml}$ penicillin and $100 \mu \mathrm{g} / \mathrm{ml}$ streptomycin. Hybridoma supernatants from 96-well plates were screened by dot blot assay with recombinant YB-1 protein for specific antibody synthesis. The positive-tested hybridoma cells were single-cell cloned twice by limited dilution in standard medium as described [37]. Immunoglobulins in the hybridoma cell culture supernatants were purified using protein A sepharose or protein G sepharose columns according to the immunoglobulin isotype $\left(\right.$ ÄKTA $_{\text {FPLC }}$ systems, Amersham Biosciences, Freiburg, Germany). F-E2G5 was of $\operatorname{IgG}_{2 b}$ isotype. Purified monoclonal antibodies were conjugated to biotin as described [38].

\section{Plasmids, cell line and transfection}

Plasmids encoding for GFP and YB-1-GFP fusion proteins (pcDNA6/V5-His-YB-1-GFP) have been described previously [20]. HEK293T cells were cultured in DME-medium containing $10 \%$ fetal bovine serum, $100 \mathrm{U} / \mathrm{ml}$ penicillin, $100 \mu \mathrm{g} / \mathrm{ml}$ streptomycin and $2 \mathrm{mM}$ L-glutamine. Transient transfections of HEK293T cells with vectors were performed by means of calcium phosphate precipitation methodology using purified endotoxin-free plasmid DNA preparations. HEK293T cells expressing the respective proteins were harvested $48 \mathrm{~h}$ after transfection and cytoplasmic and nuclear fractions were prepared by cell lysis in buffer A (10 mM HEPES [pH 7.9], $1.5 \mathrm{mM} \mathrm{MgCl}_{2}, 10$ $\mathrm{mM} \mathrm{KCl}, 0.2 \mathrm{mM}$ PMSF, $1 \mathrm{mM}$ sodium vanadate, $0.5 \mathrm{mM}$ DTT) for $10 \mathrm{~min}$ on ice, followed by centrifugation at
$2.000 \mathrm{rpm}$ for 1 minute. The supernatant corresponds to soluble cytoplasmic proteins and contains GFP and YB-1GFP proteins.

\section{Western Blotting}

SDS-PAG electrophoresis was performed with protein extracts containing GFP or YB-1-GFP protein under reducing and non-reducing conditions. Proteins were separated on $12 \%$ SDS-PAG and transferred to nitrocellulose membranes (Schleicher-Schuell, Dassel, Germany). Membranes were blocked in TTBS (10 mM Tris-HCl [pH 8.0], $150 \mathrm{mM} \mathrm{NaCl}, 0.2 \%$ Tween-20) containing 5\% non-fat dry milk for $1 \mathrm{~h}$ at room temperature. After three washing steps in TTBS, blots were incubated with biotin-labeled YB-1 Mab F-D2G5 diluted 1:2,000 and StreptABComplex diluted 1:50 (DAKO Cytomation, Glostrup, Denmark) was added. Following two more washes in TTBS the peroxidase reaction was visualized by ECL system (Amersham, Freiburg, Germany). Immunoprecipitation experiments were performed with the indicated antibodies that were incubated with pre-cleared pansorbin.

\section{ELISA}

Recombinant YB-1 protein was expressed in E. coli and affinity purified as previously described [39]. For ELISA 96-well polystyrene plates were incubated with $200 \mu \mathrm{l}$ of recombinant YB-1 protein solution $(3 \mathrm{ng} / \mu \mathrm{l})$ in coating buffer $\left(15 \mathrm{mM} \mathrm{Na}_{2} \mathrm{CO}_{3}, 35 \mathrm{mM} \mathrm{NaHCO}{ }_{3}\right.$ ) overnight at $4^{\circ} \mathrm{C}$. After four washing steps with phosphate-buffered saline with $0.05 \%$ Tween-20 (50 mM sodium phosphate, $3 \mathrm{mM}$ potassium phosphate, $150 \mathrm{mM}$ sodium chloride [pH 7.4]), blocking with 2.5\% low fat milk powder in PBS was performed at $37^{\circ} \mathrm{C}$ for $1 \mathrm{~h}$. After four additional washing steps Mabs dissolved in washing buffer at 1:50 were added to each well $(200 \mu \mathrm{l})$ and incubated another hour at $37^{\circ} \mathrm{C}$ and washed four times. Bound Mabs were detected either by incubation with $100 \mu \mathrm{l} \mathrm{HRP-conju-}$ gated polyclonal anti-mouse IgG diluted 1:1,000 in PBS/ Tween (non-biotin-labelled Mabs) or by incubation with $100 \mu$ StrepABComplex diluted 1:50 (DAKO Cytomation, Glostrup, Denmark) with biotin-labelled Mabs for 1 $\mathrm{h}$ at $37^{\circ} \mathrm{C}$ and developed with ABTS (2,2'-azino-di-3ethylbenzthiazoline-6-sulfonic acid) $/ \mathrm{H}_{2} \mathrm{O}_{2}$. One row was used as blank containing immobilised YB-1 protein but with no addition of Mabs.

\section{Immunohistochemistry}

Immunohistochemistry was performed as described recently [40] using an established breast tissue microarray [41]. The breast tissue samples of this tissue microarray were obtained from patients treated by primary surgery for breast cancer at the Department of Gynecology, University Hospital Regensburg, Germany, with institutional review board approval. All patients gave informed consent to the study for retention and analysis of their tissue for 
research purposes. Briefly, tissue sections were deparaffinized and rehydrated, and the endogenous peroxidase activity was quenched by treatment with $3 \% \mathrm{H}_{2} \mathrm{O}_{2}$. Antigen retrieval was performed by pretreatment in citrate buffer [pH 6.0] in a microwave oven (three times for 8 minutes at $600 \mathrm{~W})$. Slides were incubated with a 1:25 dilution of monoclonal biotin-labeled YB-1 antibody in 2\% milk powder dissolved in PBS in a humidified chamber overnight at $4{ }^{\circ} \mathrm{C}$. After another wash Vectastain avidin-biotin complex (Vector Laboratories, California, USA) was added for 10 minutes. Immunostaining was visualized using 3,3'-diaminobenzidine tetrahydrochloride (DAB, Sigma, Deisenhofen, Germany) and hydrogen peroxide for 5 minutes. Finally, sections were counterstained with Mayer's hematoxylin. The primary antibody was omitted for negative controls. Tissue microarray slides were analyzed by a pathologist without knowledge of clinicopathological parameters of the tumors. Nuclear YB1 staining was simply scored as positive (1) or negative (0), depending on visual inspection of tumor nuclei under high magnification $(400 \times)$. The decision to score the staining pattern according to a dichotomous criterium, nuclear versus non-nuclear staining seemed justified as the pattern was evident throughout all specimens. There was no tissue with restricted focal nuclear staining. Cytoplasmic YB-1 staining was scored according to the immunoreactivity score (IRS) system developed by Remmele and Stegner [42], subsequently tumors were grouped into low expressers (IRS 0-3) and high expressers (IRS 412). For comparison of the F-E2G5 tissue staining pattern with peptide-derived affinity-purified YB-1 antibodies, the following antibodies were utilized: YB-1\#1 has been generated by immunization and purification with a peptide corresponding to an N-terminal YB-1 epitope and was purchased from antibodies-online; YB-1\#2 has been described by Janz et al. [1])

\section{Statistical analyses of tissue microarray data}

Statistical analyses were performed with SPSS version 17.0 (SPSS, Chicago, IL). Differences were considered statistically significant when $\mathrm{p}<0.05$. Contingency table analyses and two-sided Fisher's exact tests were used to study the statistical association between clinicopathologic and immunohistochemical variables. Recurrence-free and disease-specific survival curves comparing patients with or without any of the factors were calculated using the Kaplan-Meier method, with significance evaluated by twosided log-rank statistics. Disease-specific survival and recurrence-free survival were measured from time of surgery. For the analysis of recurrence, patients were censored at the time of their last tumor-free clinical follow-up appointment. For disease-specific survival analysis, patients were censored at the time of their last tumor-free clinical follow-up appointment or at their date of death not related to the tumor. A stepwise multivariable Cox regression model was adjusted, testing the independent prognostic relevance of nuclear YB-1 immunoreactivity. The limit for reverse selection procedures was $\mathrm{p}=0.01$. The proportionality assumption for all variables was assessed with log-negative-log survival distribution functions.

\section{Multiple logistic regression model}

Regression analyses were conducted with R 2.8 (rproject.org). The binary response variable $y$ is regressed on the explanatory variables, $\mathrm{x}_{1}, \mathrm{x}_{2}, \ldots, \mathrm{x}_{\mathrm{q}}$. The model for $\mathrm{n}$ observations is defined by $\ln (\mathrm{p} /(\mathbf{1}-\mathrm{p}))=\mathrm{X} \beta+\varepsilon$, where $\varepsilon$ contains the residual error terms and $\mathrm{p}=\operatorname{Pr}(\mathrm{y}=1)$. The parameters are estimated by maximum likelihood estimation. The regression coefficients $\beta 1, \beta_{2}, \ldots, \beta q$ give the change in the response variable corresponding to a unit change in the appropriate explanatory variable, conditional on the other variables remaining constant. The intercept corresponds to the expected value of the response variable $y$ when all the explanatory variables are zero. Significance tests of whether the coefficients take the value zero can be derived on the assumption that for a given set of values of the explanatory variables, $y$ has a normal distribution with constant variance. The data was centered and scaled previous to applying logistic regression. Centering is performed by subtracting the column means (omitting missing values) of $\mathrm{x}$ from their corresponding columns, and scaling is done by dividing the (centered) columns of $\mathrm{x}$ by their root-mean-square. Explanatory variables were considered statistically significant when $\mathrm{P}<0.05$.

\section{Results \\ Characterization of monoclonal YB-I-specific antibody F- E2G5}

In a first approach the F-E2G5 antibody was examined for its substrate specificity by western blot analysis using cell extracts from HEK293 cells expressing GFP, YB-1-GFP or YB-1(21-147)-GFP proteins. GFP and YB-1-GFP fusion protein expression was ascertained by detection with monoclonal GFP antibody (Figure 1A, lanes 1-3). Immunoblotting with biotinylated F-E2G5 Mab was performed following addition of non-reducing (lanes 4-6) or reducing buffer (lanes 7-8) to protein samples. Mab F-E2G5 detects full-length YB-1-GFP fusion protein and also the truncated protein encompassing amino acids 21-147. However, detection succeeds only with non-reducing buffer and not under reducing buffer conditions with inclusion of mercaptoethanol (Figure 1A, compare lanes 5 and 7). Endogenous YB-1 protein with a relative molecular weight of $50 \mathrm{kDa}$ was not detected by immunoblotting using F-E2G5 antibody, neither in denaturing nor in non-denaturing gels (data not shown). These results indicate that (i) the epitope(s) recognized by F-E2G5 resides within the YB-1 protein domains aa21-147 and (ii) detec- 


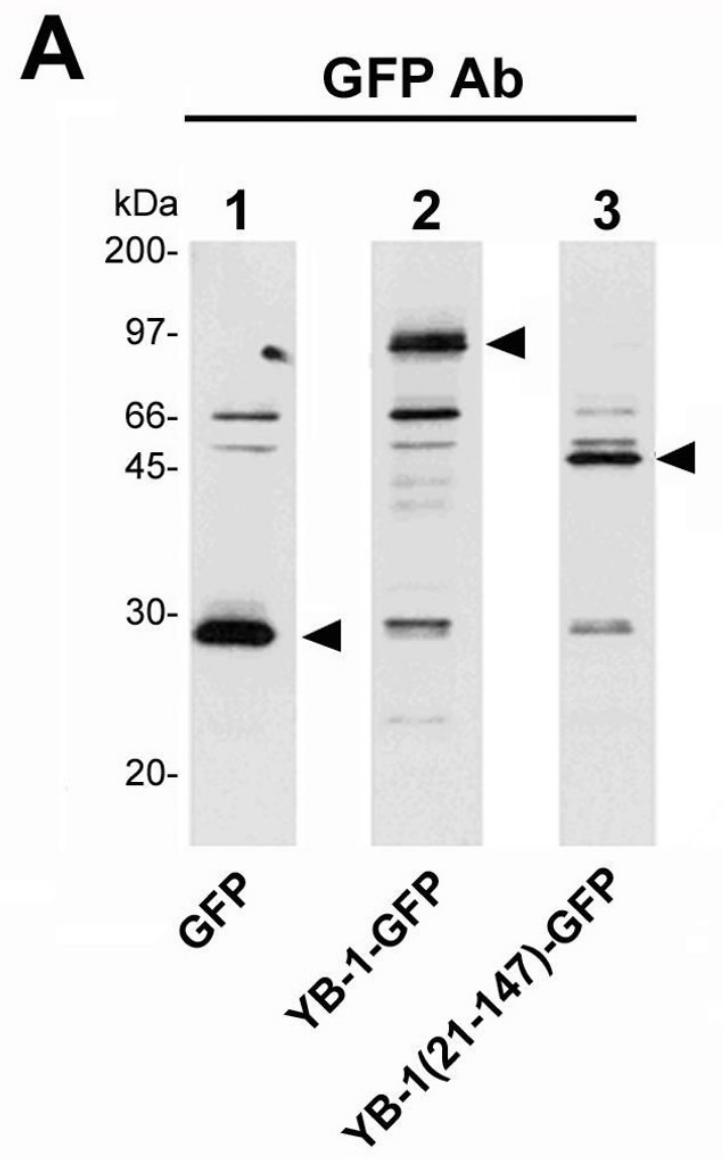

\section{F-E2G5 Ab}

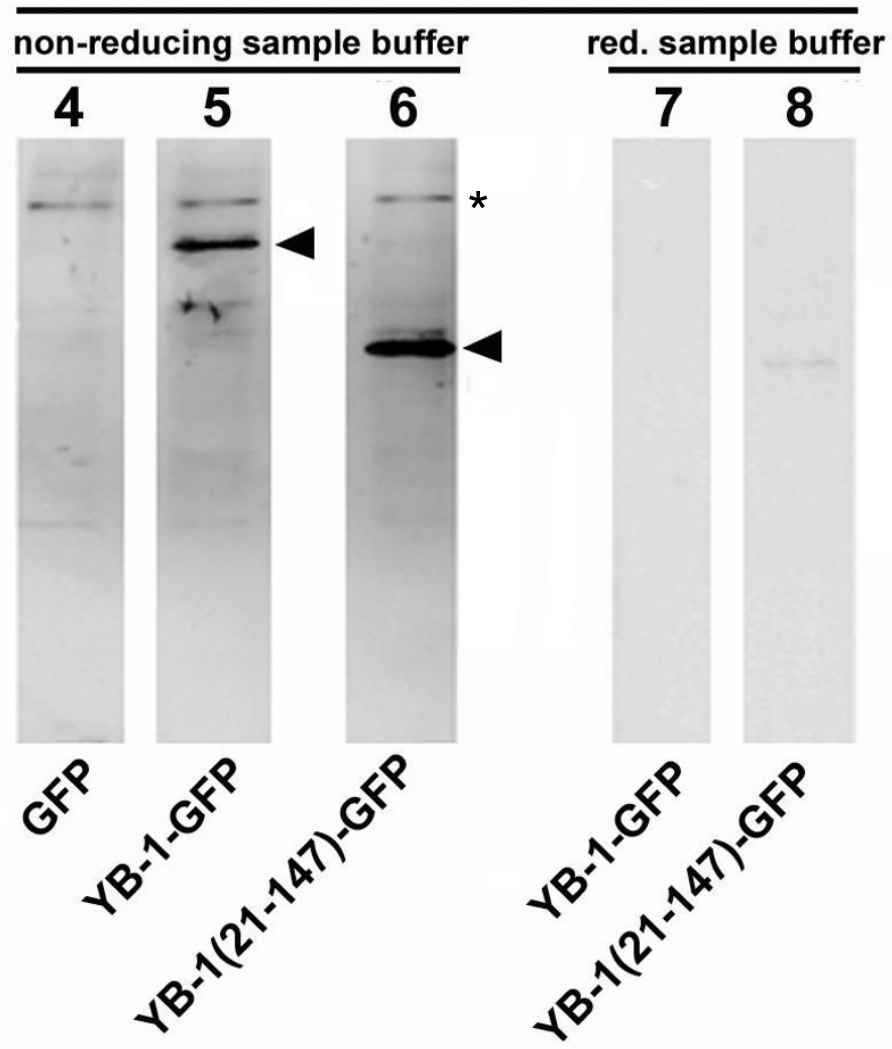

B

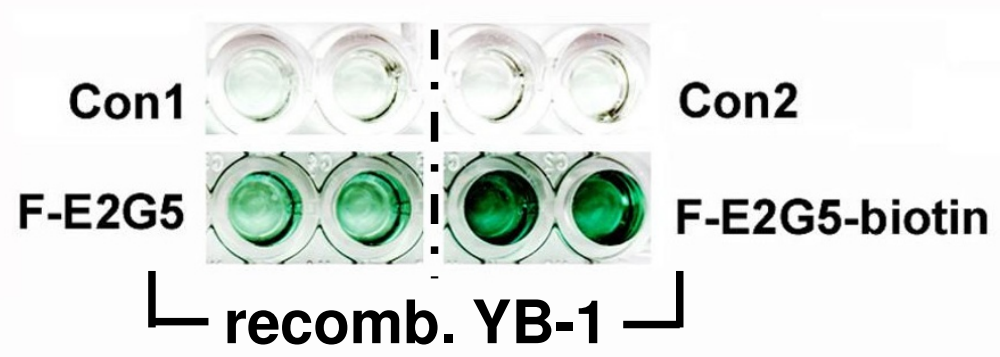

Figure I

Detection of YB-I-GFP and YB-I(2I-I 47)-GFP by immunoblot and recombinant YB-I by ELISA. (A) HEK293T cell extracts containing GFP (lanes I and 4), YB-I-GFP (lane 2, 5 and 7) or YB-I (2I-I47)-GFP proteins (lanes 3, 6 and 8) were separated in denaturing gels and following transfer to nitrocellulose probed with GFP antibody (lanes I to 3) or Mab F-E2G5 (lanes 4 to 8). Relative mobilities of expressed proteins are indicated by arrowheads. Notably, reducing sample buffer prevents detection of tagged YB-I proteins by immunoblot (lanes 7 and 8). (B) ELISA was performed by coating with recombinant affinity purified hexahistidin-tagged YB-I protein. Biotin-labeled Mab F-E2G5 yields an even stronger signal than non-biotinylated Mab. Controls included omission of antibody (Conl) or antigen (Con2).

tion is highly susceptible to the chosen conditions of western blotting.

One may conclude that the GFP-tag stabilizes the YB-1 protein conformation and permits successful detection by means of Mab F-E2G5, as the endogenous YB-1 protein from cell lysates ( $\sim 50 \mathrm{kDa})$ was not detected by western blotting (only minute amounts were immunopositive following prolonged exposure). To ensure that Mab F-E2G5 successfully binds YB-1 protein under non-reducing and 
non-denaturing conditions, we thereafter established a direct ELISA with recombinant, affinity-purified YB-1 protein expressed in E. coli. Biotinylated as well as non-biotinylated Mabs F-E2G5 were tested. Under both conditions recombinant YB-1 protein was detected (Figure 1B), even better with biotinylated Mab F-E2G5. Controls included omission of antibody (Con1) or antigen (Con2) and addition of irrelevant IgG2/irrelevant biotinylated IgG2 antibody (not shown), all yielding negative results. Thus, Mab F-E2G5 binds epitope(s) that reside within YB-1 protein domains aa21 to 147 . In addition, a sandwich ELISA was established with a series of GFP-tagged fusion proteins that include the following domains of YB-1 protein: aa21-147, aa146-317, aa146-225, aa146-172, aa260-317, aa146-262, aa21-262. Biotinylated Mab F-E2G5 was able to detect all fusion proteins that encompassed aa146-172. ELISA results were scored positive with an optical density of $>0.4$, whereas background values were below 0.05 . These results support the notion that two distinct conformational epitopes are recognized by the Mab, one within the N-terminal (aa21-147) and one within the centrally localized domains (aa146-172).

To further evaluate the propensity of Mab F-E2G5 to associate with YB-1-GFP or endogenous YB-1 proteins Mab FE2G5 was evaluated in immunoprecipitation studies (Figures $2 \mathrm{~A}$ and $2 \mathrm{~B}$ ). Mab F-E2G5 successfully pulled down YB-1-GFP, that was subsequently detected by monoclonal anti-GFP-tag antibody (Figure 2A). Furthermore Mab FE2G5 immunoprecipitated endogenous YB-1 protein from HEK293 whole cell extracts, with immunoprecipitated protein being detected by polyclonal peptidederived anti-YB-1 antibody directed against the protein $\mathrm{C}$ terminus (denoted YB-1(C-term), Figure 2B, lane 2).

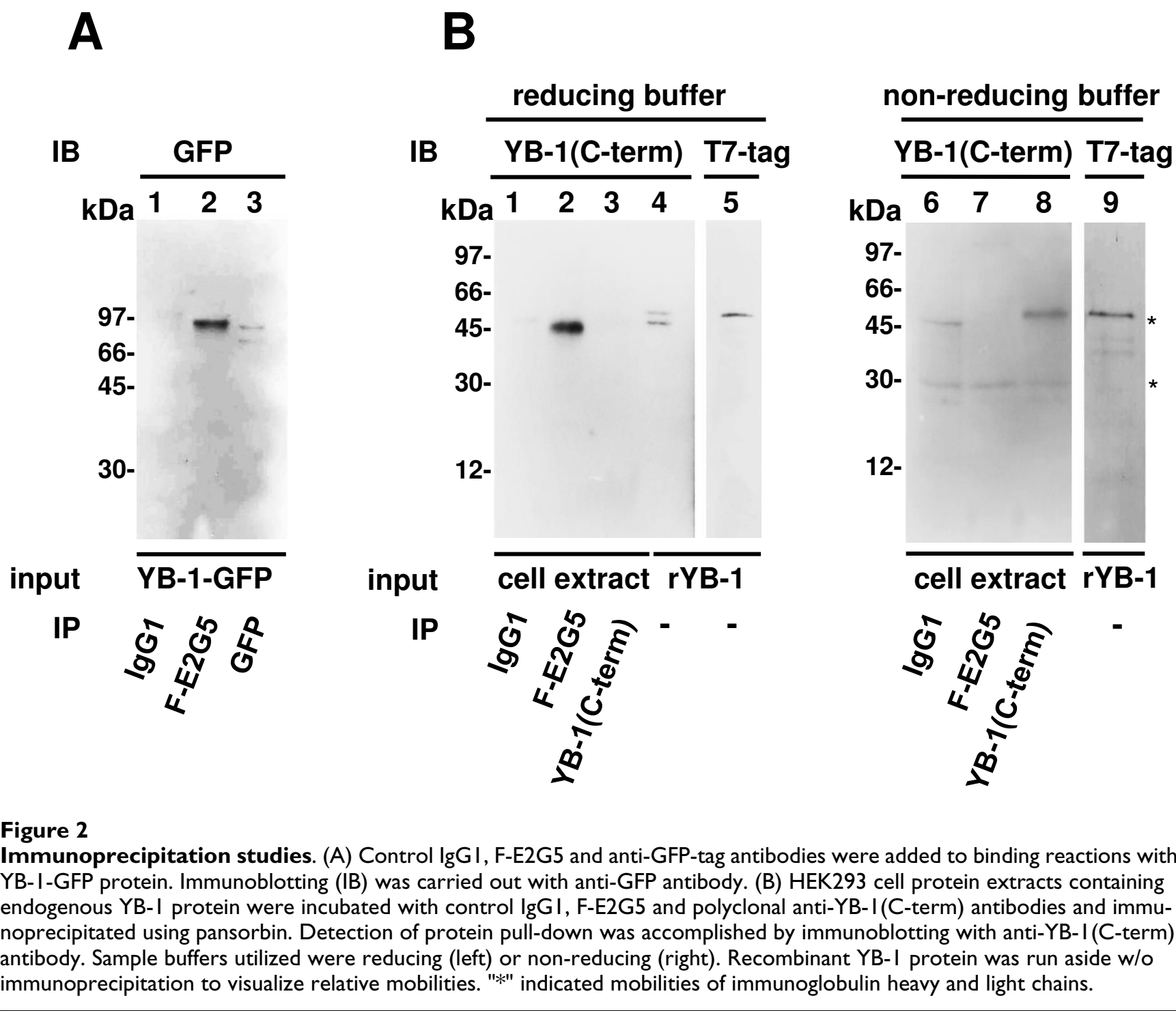


Notably, when endogenous YB-1 protein was immunoprecipitated by polyclonal anti-YB-1(C-term) immunoblotting was unsuccessful under reducing conditions (Figure 2B, lane 3).

Next immunoprecipitated proteins were loaded on gels in non-reducing buffer (omission of mercaptoethanol and EDTA). Under these conditions immunoprecipitated endogenous YB-1 pulled down by monoclonal F-E2G5 antibody was no longer detected with polyclonal anti-YB1(C-term) antibody. Successful immunoprecipiation by anti-YB-1(C-term) antibody was however possible (Figure 2B, lane 8). Heavy and light chains from immunoglobulins, that are contaminants from the immunoprecipitation procedure, were detected in samples loaded under non-reducing buffer conditions (indicated by "*" in Figure $2 \mathrm{~B})$.

From these results it is concluded that monoclonal FE2G5 antibody has the propensity to immunoprecipitate YB-1-GFP as well as endogenous YB-1 protein, however, detection by means of immunoblotting with the utilized polyclonal anti-YB-1 antibody is susceptible to the chosen buffer conditions.

\section{Mab F-E2G5 is suitable for YB-I immunodetection in formalin-fixed paraffin-embedded breast cancer tissue}

From our previous studies it was clear that the fixation procedure markedly affects detection of YB-1 in rat tissue [43]. In the following we performed immunohistochemistry of sequential tissue sections from patients diagnosed with invasive breast cancer. Biotinylated Mab F-E2G5 and two polyclonal peptide-derived YB-1 antibodies generated against distinct epitopes within the protein N-terminus were utilized. Notably, one of the polyclonal antibodies used (YB-1\#2) has been previously applied by Janz et al. [1], the other is commercially available (YB-1\#1; see Materials). Sequential sections were stained for Ki67 to identify cycling cells and exclude the possibility that biotinylated Mab F-E2G5 merely detects such cells. As can be seen in Figure 3 there was strong cytoplasmatic staining of cancerous cells with both polyclonal antibodies (\#1 and \#2). The overall pattern of immunopositive cells was similar with the Mab, however, a considerable fraction of cells exhibited strong nuclear staining. Ki67 positivity was observed in about 10 to $25 \%$ of all tumor cells, which was considerably lower than YB-1 positive cells detected by Mab F-E2G5. This finding excludes the possibility that the Mab only detects cycling cells.

From these results we conclude that the established Mab F-E2G5 is suitable for immunohistochemistry with formalin-fixed paraffin-embedded tissue, as routinely performed for histological analyses. The overall staining pattern with Mab and polyclonal antibodies is similar. However, Mab F-E2G5 preferentially detects nuclear YB-1.

\section{Nuclear YB-I staining pattern in breast cancer tissue}

Immunohistochemical analysis was used to investigate YB-1 protein expression in normal breast tissue and breast cancers. We analyzed a tissue microarray with 224 breast tissue samples, i.e. 179 invasive ductal carcinomas, eight ductal carcinoma in situ (DCIS) and 37 normal breast tissue samples. To our knowledge, the latter group is larger than all other control groups analyzed by immunohistochemistry for YB-1 expression so far. Nuclear YB-1 immunohistochemical staining was only detectable in invasive ductal carcinomas, but not in DCIS and normal breast tissue. Figure 4 shows representative images of YB-1 expression in normal and malignant breast tissues. YB-1 staining was not detectable in normal breast tissue (Figures $4 \mathrm{~A}$ and $4 \mathrm{~B}$ ). In DCIS (Figures 4C and 4D) cytoplasmic YB-1 expression was present in $75 \%(6 / 8)$ of cases, while nuclear YB-1 expression was not present. Invasive ductal carcinomas exhibited nuclear staining in $24 \%(43 / 179)$ of cases (Figures 4E and 4F).

\section{YB-I expression, clinico-pathological parameters and patient survival}

Clinicopathologic and immunohistochemical characteristics were correlated with nuclear and cytoplasmic YB-1 staining for descriptive data analysis (Table 1). Cytoplasmic YB-1 expression detected with the Mab F-E2G5 was not significantly correlated to overall $(\mathrm{p}=0.134)$ and recurrence-free survival $(\mathrm{p}=0.39)$.

However, nuclear YB-1 expression detected by antibody FE2G5 was associated with shorter overall survival (OS; $\mathrm{p}=$ 0.0046) and exhibited a strong trend towards association with shorter recurrence-free survival (RFS; $\mathrm{p}=0.09$ ). These were compared by Kaplan Meier analysis between invasive breast tumours with nuclear YB-1 expression versus all other invasive breast tumours exhibiting no nuclear expression (Figure 5). Patients with nuclear YB-1 expression in the tumor had an estimated mean OS of 90 months (95\% confidence interval (CI): 72-109 months) compared to 117 months (95\% CI: 108-126 months) in patients with absent nuclear YB-1 immunoreactivity. Nuclear YB-1 detection also correlated with tumor stage $(\mathrm{p}=0.004)$, higher $(\mathrm{G} 2 / \mathrm{G} 3)$ histological grade $(\mathrm{p}=$ $0.011)$ and negativity of progesterone receptor status $(\mathrm{p}=$ 0.002 ) (Table 1). These strong correlations are demonstrated in Figure 6. In a stratified univariate analysis, the prognostic value of nuclear YB-1 detection became even more pronounced in the clinically important subgroup of stage pT1/T2 tumors, representing $~ 80 \%$ of all diagnosed carcinomas, and breast tumors with negative progesterone receptor status (Figures 6 and 7 ). While pT1 tumours exhibit no prominent nuclear YB-1 staining (Figure 7A), 

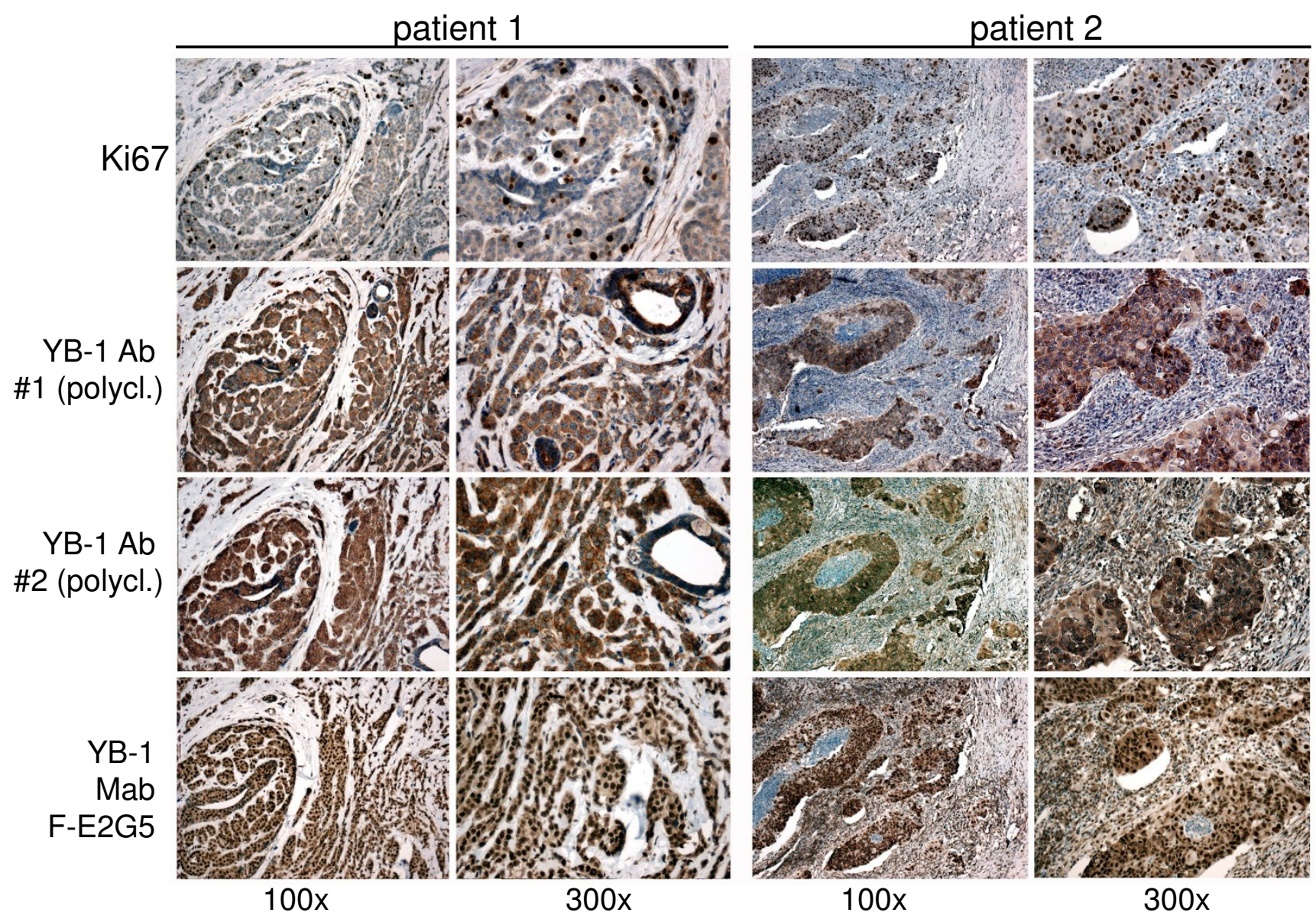

Figure 3

Immunohistochemical comparison of different YB-I antibodies in human invasive breast cancer. While the proliferation marker $\mathrm{Ki67}$ is strongly expressed in a defined fraction of breast tumor cells there is no concordance to the expression pattern of YB-I. The three YB-I antibodies present very similar expression patterns. However, while the two established polyclonal YB-I antibodies (\#I is against an N-terminal epitope and available from antibodies-online; \#2 has been established by Janz et al. [I]) predominantly detect cytoplasmic YB-I expression, the newly characterized monoclonal YB-I antibody Mab FE2G5 is able to detect nuclear YB-I besides less abundant expression in the cytoplasm.

distinct nuclear YB-1 staining was detectable in pT4 tumours (B). In a similar comparison nuclear YB-1 protein was not detectable in most progesterone receptor positive breast tumours (Figure 7C), while there was prominent nuclear YB-1 staining in most tumors with negative progesterone receptor status (D).

Cox regression models including factors possibly influencing tumor-related survival and recurrence-free survival in relation to nuclear YB-1 expression were applied. As could be expected due to the size of our cohort, this analysis failed to demonstrate significance for nuclear YB1 detection as an independent prognostic marker (Table 2). Subsequently we analyzed nuclear YB-1 expression with respect to the molecular breast cancer subtypes defined by Perou and Sorlie [44,45]. A multiple logistic regression model was calculated with nuclear YB-1 expression as target variable and CK5/6, ER and HER2 as covariates (Table 3 ). None of the tested covariates remained significant; i.e., none of the covariates was significantly correlated with nuclear YB-1 expression, arguing that YB-1 is not selectively expressed in a specific molecular subtype of breast cancer.

\section{Discussion}

Major challenges in cancer diagnostics relate to early detection of malignant tissue and the possibility to predict the rate of disease progression and sensitivity to chemotherapy. Regarding all these issues the Y-box protein-1 may gain a prominent role, given that (i) it has an oncogenic property with induction of breast tumors in $100 \%$ of transgenic animals overexpressing YB-1 in the mam- 

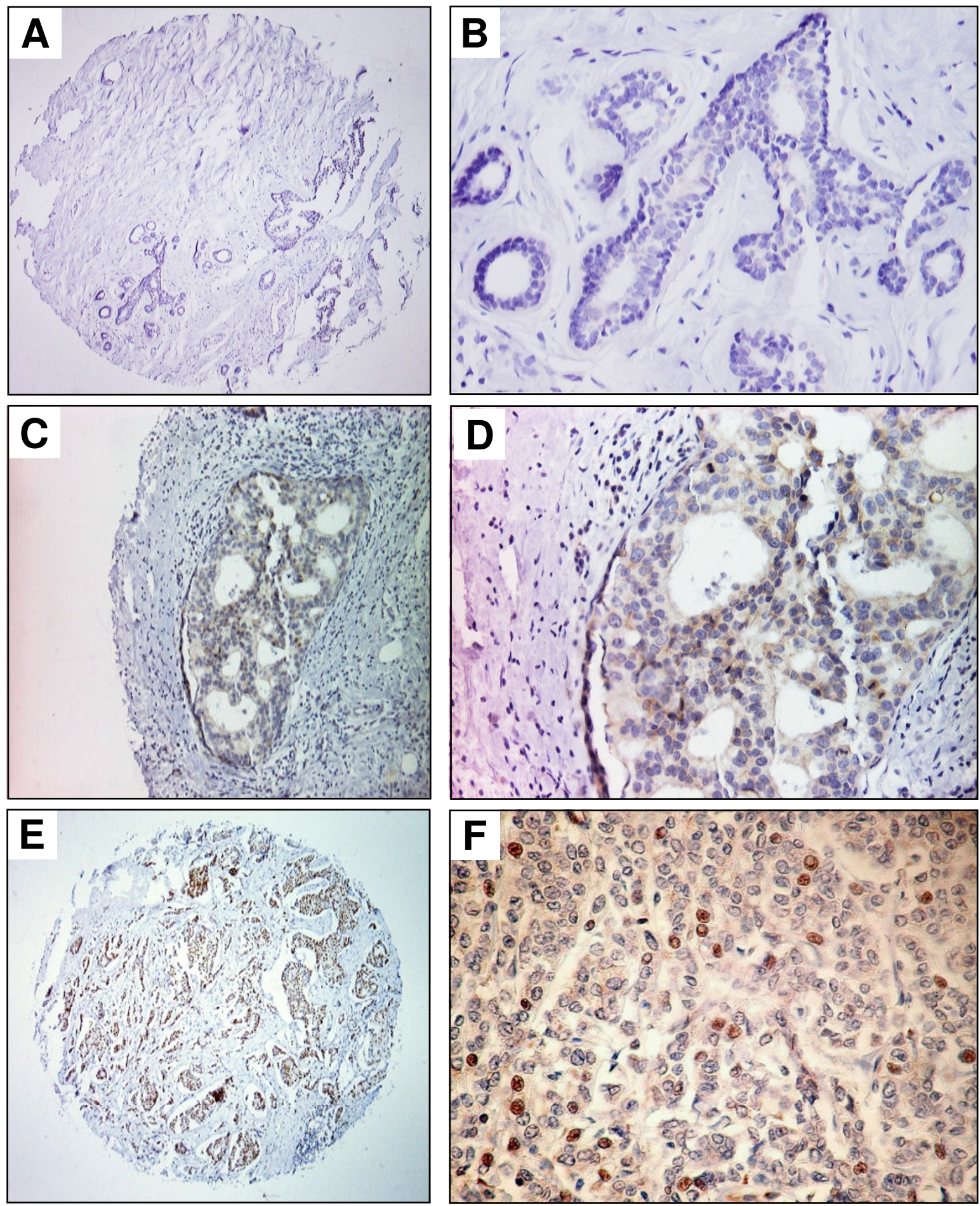

\section{Figure 4}

Expression of YB-I in normal breast tissue, non-invasive and invasive breast cancer. (A) Only weak cytoplasmic YB-I staining is detectable in normal breast tissue. (B) Scale-up of specimen shown in A. The magnification demonstrates weak YB-I expression in luminal-epithelial breast cells. (C) Moderate YB-I expression in a ductal carcinoma in situ (DCIS) of the breast. (D) Scale-up of specimen shown in C. (E) Invasive ductal breast cancer with abundant nuclear $Y B-I$ expression. (F) Scale-up of specimen shown in E. Magnifications: A, C, E: I00x; B, D, F: 400x. 
Table I: Clinico-pathological and immunohistochemical parameters in relation to YB-I immunoreactivity, and univariate analysis of factors regarding tumor-related and recurrence-free surival

\begin{tabular}{|c|c|c|c|c|c|c|c|c|c|c|c|}
\hline \multirow[t]{2}{*}{ Variable } & \multirow[t]{2}{*}{ Categorization } & \multicolumn{4}{|c|}{ Nuclear YB-I immunoreactivity } & \multicolumn{3}{|c|}{ Tumor-related death } & \multicolumn{3}{|c|}{ Tumor recurrence } \\
\hline & & n analyzable & neg. & pos. & $\mathbf{p}^{*}$ & $\mathbf{n}$ & events & $\mathbf{p}^{\dagger}$ & $\mathbf{n}$ & events & $\mathbf{p}^{\dagger}$ \\
\hline \multicolumn{12}{|c|}{ Clinico-pathological data: } \\
\hline \multicolumn{12}{|c|}{ Age at diagnosis } \\
\hline & $<50$ years & 51 & 43 & 8 & 0.036 & 51 & 9 & 0.0064 & 51 & 16 & 0.1895 \\
\hline & $\geq 50$ years & 108 & 74 & 34 & & 108 & 45 & & 102 & 42 & \\
\hline \multicolumn{12}{|l|}{ Tumor stage } \\
\hline & PTI & 40 & 35 & 5 & 0.004 & 40 & 4 & $<0.0001$ & 39 & 5 & 0.0001 \\
\hline & pT2 & 83 & 63 & 20 & & 83 & 28 & & 81 & 34 & \\
\hline & PT3 & 10 & 4 & 6 & & 10 & 4 & & 9 & 4 & \\
\hline & pT4 & 26 & 15 & 11 & & 26 & 18 & & 24 & 15 & \\
\hline \multicolumn{12}{|l|}{ Lymph node status } \\
\hline & pNo & 75 & 60 & 15 & 0.101 & 75 & 11 & $<0.0001$ & 74 & 13 & $<0.0001$ \\
\hline & pNI-3 & 80 & 54 & 26 & & 80 & 41 & & 76 & 42 & \\
\hline \multicolumn{12}{|l|}{ Histologic grade } \\
\hline & GI & 17 & 16 & 1 & 0.011 & 17 & 4 & 0.0047 & 17 & 4 & $<0.0001$ \\
\hline & $\mathrm{G} 2$ & 69 & 55 & 14 & & 69 & 17 & & 65 & 16 & \\
\hline & G3 & 73 & 46 & 27 & & 73 & 33 & & 71 & 38 & \\
\hline \multicolumn{12}{|l|}{ Multifocality } \\
\hline & unifocal tumor & $14 \mid$ & 104 & 37 & 1.000 & $14 \mid$ & 45 & 0.0903 & 136 & 49 & 0.0683 \\
\hline & multifocal tumor & 18 & 13 & 5 & & 18 & 9 & & 17 & 9 & \\
\hline \multicolumn{12}{|l|}{ Histologic type } \\
\hline & ductal & 125 & 93 & 32 & 0.710 & 125 & 43 & 0.9302 & 123 & 49 & 0.5730 \\
\hline & lobular & 16 & 11 & 5 & & 16 & 5 & & 14 & 4 & \\
\hline & other & 15 & 10 & 5 & & 15 & 5 & & 13 & 4 & \\
\hline \multicolumn{12}{|c|}{ Immunohistochemistry (IHC): } \\
\hline \multicolumn{12}{|c|}{ Estrogen receptor status } \\
\hline & negative & 42 & 30 & 12 & 1.000 & 42 & 19 & 0.0129 & 42 & 24 & 0.0026 \\
\hline & positive & 96 & 69 & 27 & & 96 & 25 & & 92 & 27 & \\
\hline \multicolumn{12}{|c|}{ Progesterone receptor status } \\
\hline & negative & 98 & 63 & 35 & 0.002 & 98 & 40 & 0.0045 & 93 & 44 & 0.0019 \\
\hline & positive & 46 & 41 & 5 & & 46 & 8 & & 46 & 9 & \\
\hline \multicolumn{12}{|l|}{ Cytokeratin $5 / 6 \mathrm{IHC}$} \\
\hline & negative $(0)$ & 118 & 85 & 33 & 0.540 & 118 & 34 & 0.0100 & 114 & 38 & 0.0349 \\
\hline & positive $(1+-3+)$ & $4 I$ & 32 & 9 & & 41 & 20 & & 39 & 20 & \\
\hline \multicolumn{12}{|l|}{ TP53 IHC } \\
\hline & $<10 \%$ & 85 & 62 & 23 & 1.000 & 85 & 28 & 0.3823 & 82 & 28 & 0.4422 \\
\hline & $\geq 10 \%$ & 48 & 31 & 17 & & 48 & 18 & & 46 & 19 & \\
\hline \multicolumn{12}{|l|}{ HER2 IHC } \\
\hline & negative $(0-1+)$ & 108 & 83 & 25 & 1.000 & 108 & 28 & 0.0081 & 102 & 31 & 0.0008 \\
\hline & positive $(2+-3+)$ & 35 & 21 & 14 & & 35 & 18 & & 35 & 20 & \\
\hline
\end{tabular}

* Fisher's exact test (two-sided), bold face representing significant data.

† Log rank test (two-sided), bold face representing significant data.

mary gland [23], (ii) analyses of dysplasia-associated lesions in colitis ulcerosa patients reveal that lesions with increased cancer risk are distinguishable due to their YB-1 expression pattern [46], (iii) several reports on breast cancer indicate that YB-1 expression levels are strongly predictive for relapse rates and negatively correlate with disease free survival [6,34,36,47-50], and (iv) YB-1 upregulated Pglycoprotein expression. To date, however, no clear-cut standard for the assessment of YB-1 expression levels is available. In most immunohistochemical analyses overall expression levels have been scored in cancer tissues. Janz et al. even included the YB-1 expression within the adjacent tissue for analyses, which profoundly improved the predictive value on relapse-free survival [1].

One of the major obstacles towards a unifying scoring system in cancer tissue is the lack of a common expression pattern observed with diverse antibodies directed against YB-1. Most antibodies provide a highly specific staining pattern that is confined to the cytoplasm with complete absence within the nuclear compartment, as also reported in the most recent and largest study performed hitherto 


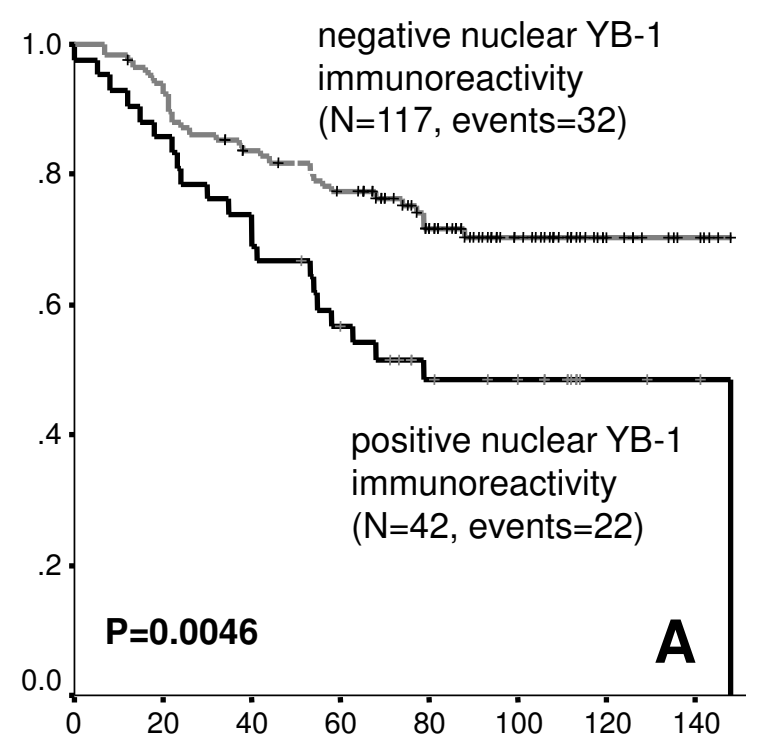

Tumor-related survival (months)

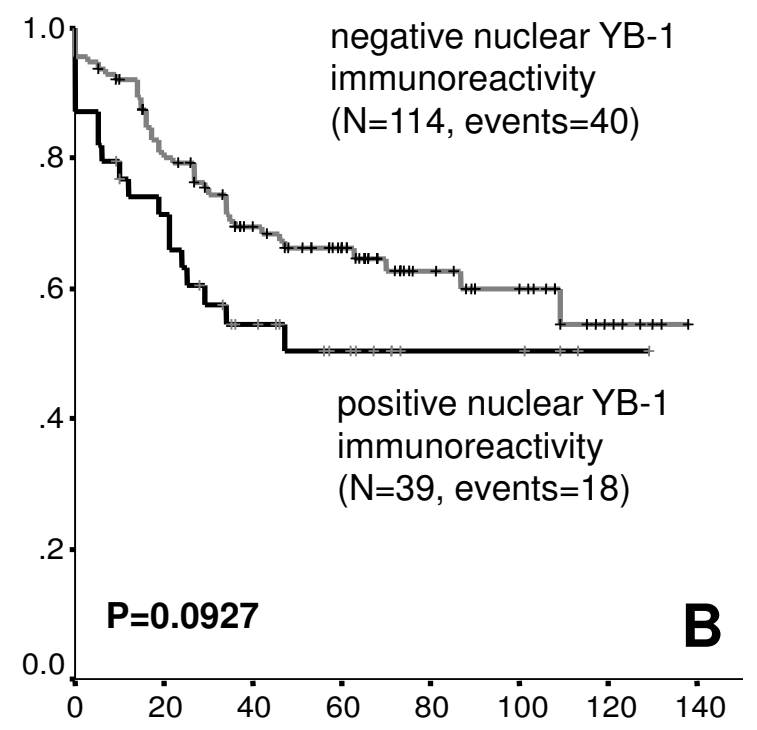

Recurrence-free survival (months)

Figure 5

$A$ and B: Distribution of time (months) to tumor-related death (A) and tumor recurrence (B) among breast cancer patients with negative and positive YB-I immunoreactivity as estimated by the method of Kaplan and Meier.

[6]. On the other hand, most - if not even all - activities of YB-1, that relate to oncogenic transformation, cell proliferation and drug resistance, must take place within the nuclear compartment. These are accompanied by altered gene transcription as well as chromosomal instability $[18,20,23]$. Thus, it is conceivable that a sensitive detection system and valid predictive testing must include such information, which is also reiterated by the observation of nuclear YB-1 being associated with P-glycoprotein expression and drug resistance $[8,11]$. It becomes even more complex when one envisions that YB-1 is a quite abundant cytoplasmic protein and has been detected in the nucleus in non-transformed cells as well, when tissue is fixed in Carnoys fixative [43]. The question is therefore, how these inconsistencies may be reconciled. One answer may be that YB-1 in cancer tissue has a different antigenicity due to post-translational modifications, e.g. phosphorylation of serine 102 [27]. In line with this interpretation is the observation of nuclear as well as cytoplasmic YB-1 in most cells using immunoblotting and senescence of cells with YB-1 knock-out [18,51]. Alternatively, cleavage of YB-1 within the protein C-terminus, as proposed before via the 20S proteasome [52,53], may render epitopes of YB-1 accessible for antibodies and result in positive immunodetection. Sorokin et al. have nicely demon- strated that the cleaved $\mathrm{N}$-terminal fragment itself may shuttle to the nucleus and predict chemoresistance, whereas the overall full-length YB-1 expression level was unchanged in chemotherapy resistant versus chemosensitive cells. Attempts to explain the hidden secret beyond the different detection patterns observed already hint at the difficulties that the design and establishment of a monoclonal antibody to detect YB-1 faces.

In this report, we describe the generation of a monoclonal YB-1 antibody, termed F-E2G5, which detects YB-1 in formaldehyde-fixed paraffin-embedded tissues. Specificity of YB-1 detection by this antibody was confirmed by immunoblotting with YB-1-GFP fusion protein and ELISA. One detected epitope must reside within the central domains encompassing amino acids 21-147, a second one within domains aa146-172. Notably, using this antibody endogenous YB-1 protein is not detected by immunoblotting, likely due to its "misfolding" under the given conditions. Likely, that the GFP-tag within the protein C-terminus stabilizes the recognized epitope(s) for detection by western blotting. A non-specific band detected under some immunoblotting conditions does not seem to be of relevance for the performed immunohistochemistry, given that tissue specimens from healthy breast tissue do not demonstrate 
Stage pT1-2:

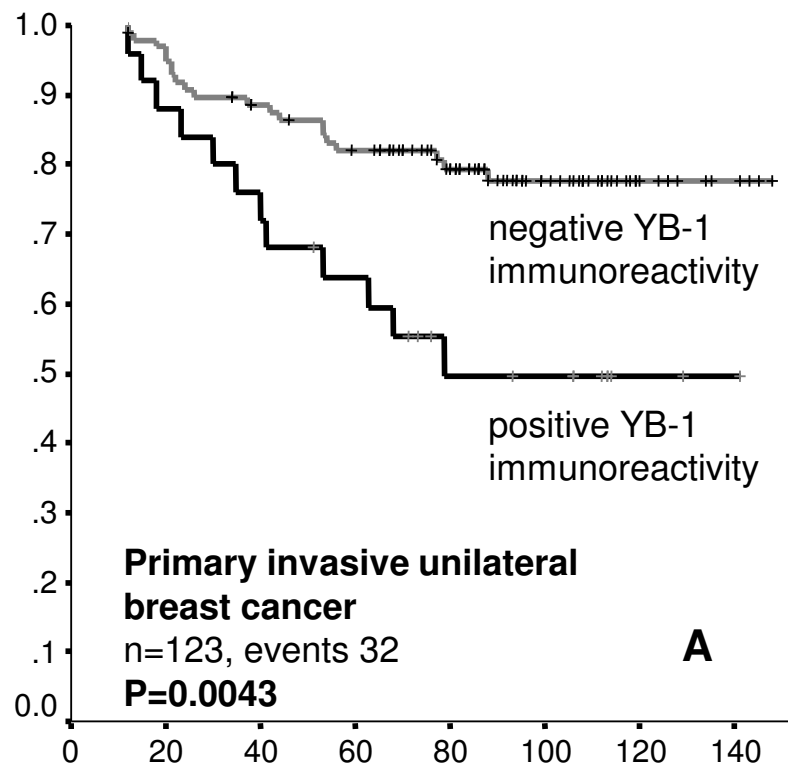

Tumor-related survival (months)

Negative PR status:

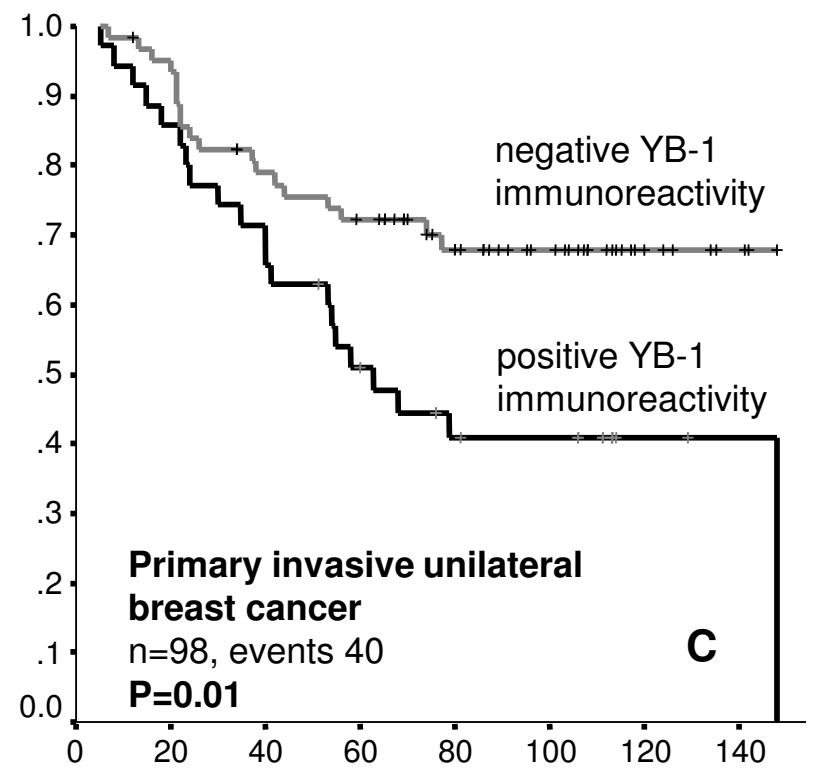

Tumor-related survival (months)

\section{Stage pT3-4:}

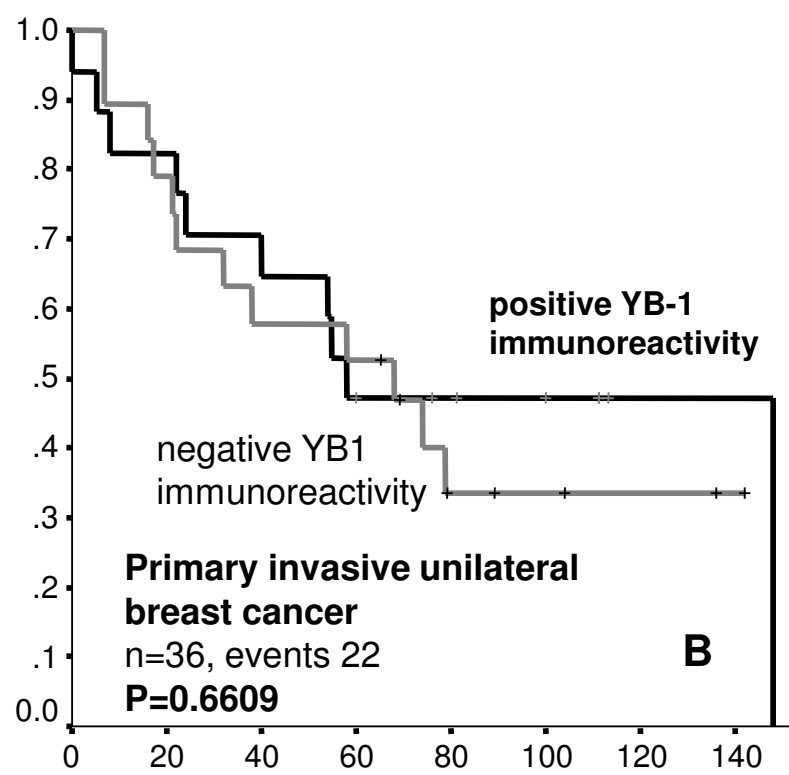

Tumor-related survival (months)

Positive PR status:

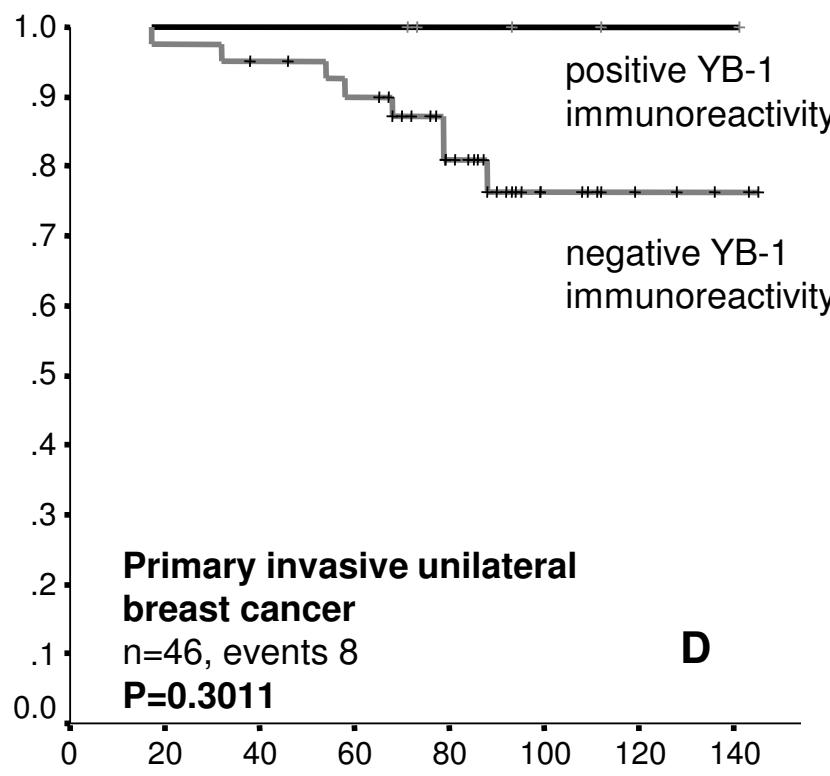

Tumor-related survival (months)

Figure 6

A -- D: Distribution of time (months) to tumor-related death among the various subgroups (A, pT I-2; B, pT34; C, negative progesterone receptor status; D; positive progesterone receptor status) of breast cancer patients with negative and positive YB-I immunoreactivity as estimated by the method of Kaplan and Meier. 


\section{pT1}

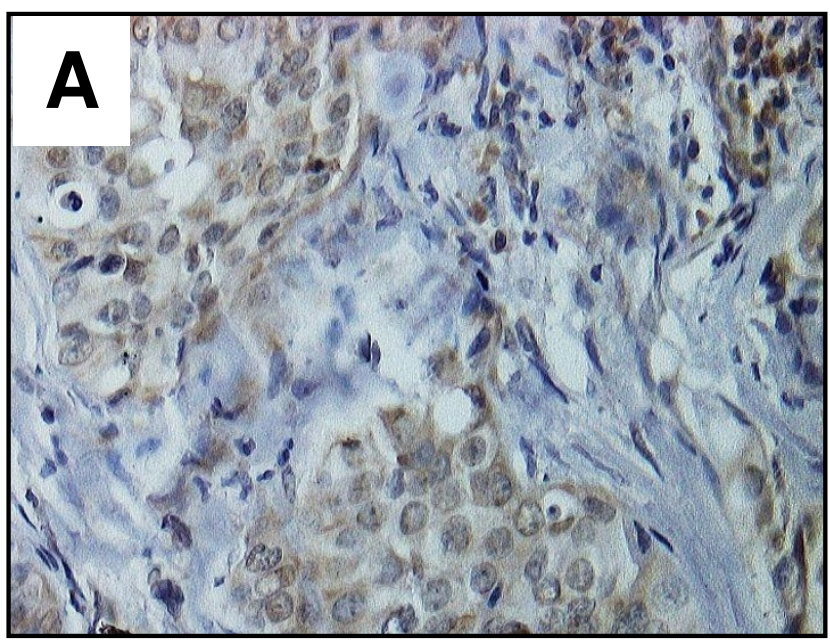

\section{PR +}

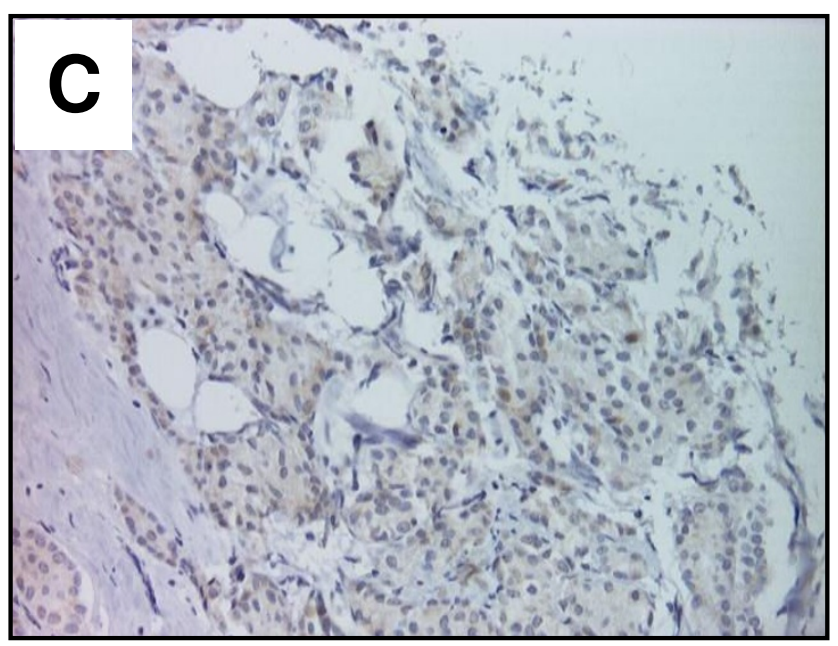

pT4

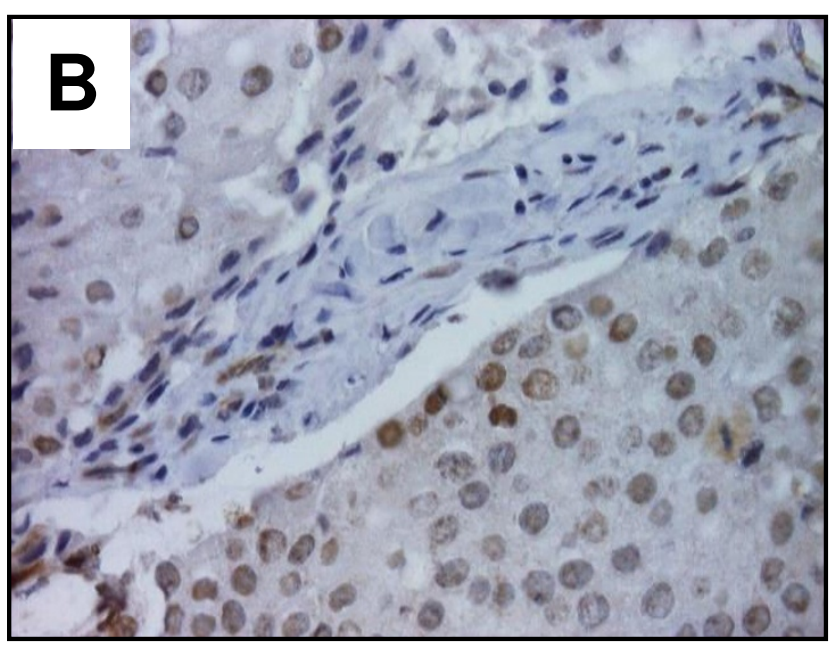

PR -

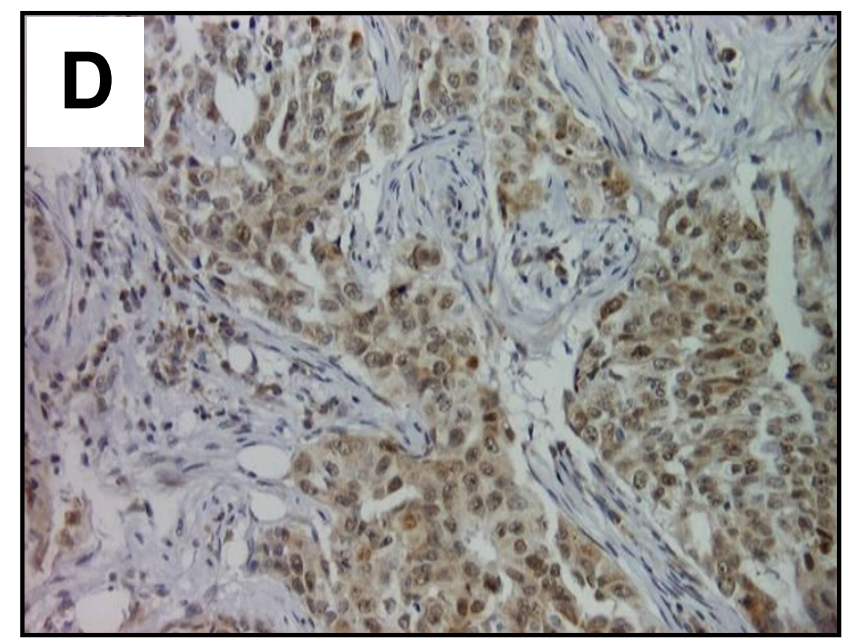

Figure 7

Representative tissue microarray staining results illustrating $Y B-I$ expression in relation to tumor stage (A and $B$ ) and progesterone receptor status (C and D). A and B: While YB-I staining in small (PTI) tumors is predominantly cytoplasmic $(A)$, large (pT4) tumors preferentially show a distinct condensation of YB-I signal in the nuclei of tumor cells (B). C and D: In breast tumors with positive progesterone receptor status (C) YB-I expression is predominantly cytoplasmic, while tumors that lost progesterone receptor expression (D) exhibit prominent nuclear YB-I expression.

immunopositivity with Mab F-E2G5 and correlation results indicate that the outcome correlates with a nuclear staining pattern.

We have used this antibody to analyze YB-1 expression in a large and clinically well characterized collection of breast cancer specimens [41] that has previously been suc- cessfully used to define novel breast tumor markers [40]. Unlike Abba et al. [54] who described an absence of YB-1 mRNA expression in DCIS compared to normal tissues, we found an increased cytoplasmic concentration of YB-1 protein in six of eight analyzed DCIS compared to normal tissue. In our study, nuclear YB-1 expression was restricted to invasive ductal carcinomas. Conversely, tissue sections 
Table 2: Multivariate Cox regression analysis of factors possibly influencing tumor-related survival and recurrence-free survival

\begin{tabular}{|c|c|c|c|c|c|c|c|c|c|c|c|}
\hline \multirow{3}{*}{ Name } & \multirow{3}{*}{ Variables } & & \multirow{3}{*}{ Categorisation } & \multicolumn{4}{|c|}{ Tumor-related survival } & \multicolumn{4}{|c|}{ Recurrence-free survival } \\
\hline & & & & \multirow{2}{*}{$\begin{array}{c}\text { Global } \\
\text { p }^{*}\end{array}$} & \multicolumn{3}{|c|}{ Stepwise reverse selection ${ }^{\dagger}$} & \multirow{2}{*}{$\begin{array}{c}\text { Global } \\
\mathbf{p}^{*}\end{array}$} & \multicolumn{3}{|c|}{ Stepwise reverse selection ${ }^{\dagger}$} \\
\hline & & & & & $\begin{array}{c}\text { Hazard } \\
\text { ratio }\end{array}$ & $\begin{array}{c}95 \% \\
\text { Confidence } \\
\text { interval }\end{array}$ & $\mathbf{p}$ & & $\begin{array}{l}\text { Hazard } \\
\text { ratio }\end{array}$ & $\begin{array}{c}95 \% \\
\text { Confidence } \\
\text { interval }\end{array}$ & $\mathbf{p}$ \\
\hline \multicolumn{12}{|c|}{ Model with dichotomous covariables } \\
\hline \multirow[t]{2}{*}{$\mathrm{T}$} & Tumor stage & 0 & PTI-2 & 0.402 & & - & & 0.153 & & - & \\
\hline & & 1 & PT3-4 & & & & & & & & \\
\hline \multirow[t]{2}{*}{$N$} & $\begin{array}{l}\text { Lymp node } \\
\text { status }\end{array}$ & 0 & pNO & 0.002 & 5.050 & $2.264-11.267$ & $<0.001$ & 0.038 & 2.934 & $1.303-6.607$ & 0.009 \\
\hline & & 1 & pNI-3 & & & & & & & & \\
\hline \multirow[t]{2}{*}{ G } & $\begin{array}{l}\text { Histologic } \\
\text { grade }\end{array}$ & 0 & GI-2 & 0.136 & 1.875 & $0.946-3.715$ & 0.072 & 0.007 & 3.188 & I.442-7.052 & 0.004 \\
\hline & & 1 & G3 & & & & & & & & \\
\hline \multirow[t]{2}{*}{ ER } & Estrogen & 0 & negative & 0.168 & 0.420 & $0.213-0.829$ & 0.012 & 0.047 & 0.357 & $0.173-0.733$ & 0.005 \\
\hline & & 1 & positive & & & & & & & & \\
\hline \multirow[t]{2}{*}{ HER2 } & HER2 IHC & 0 & negative $(0-1+)$ & 0.386 & & - & & 0.045 & 2.164 & $1.019-4.594$ & 0.045 \\
\hline & & 1 & positive $(2+-3+)$ & & & & & & & & \\
\hline \multirow[t]{2}{*}{$\mathrm{CK} 5 / 6$} & $\begin{array}{l}\text { Cytokeratin } \\
5 / 6 \mathrm{IHC}\end{array}$ & 0 & negative $(0)$ & 0.085 & & - & & 0.305 & & - & \\
\hline & & 1 & positive $(1+-3+)$ & & & & & & & & \\
\hline \multirow[t]{2}{*}{ TP53 } & TP53 IHC & 0 & $<10 \%$ & 0.607 & & - & & 0.043 & 0.529 & $0.256-1.092$ & 0.085 \\
\hline & & 1 & $\geq 10 \%$ & & & & & & & & \\
\hline \multirow[t]{2}{*}{ YBI } & YBI IHC & 0 & negative $(0)$ & 0.530 & & - & & 0.738 & & - & \\
\hline & I & $\begin{array}{l}\text { positive } \\
(1+-3+)\end{array}$ & & & & & & & & & \\
\hline
\end{tabular}

representing DCIS or normal breast tissue did not show nuclear expression of YB-1. Concordantly with these observations, nuclear expression of YB-1 in invasive breast cancer was significantly associated with overall survival ( $\mathrm{p}$ $=0.0046$ ). In our cohort this correlation was more predictive as observed by Janz et al. [1], who found a less tight association between YB-1-linked tumor aggressiveness and poor clinical outcome $(\mathrm{p}=0.011)$.

So far we are the first group that describes a correlation between nuclear YB-1 expression and increased tumor grading $(\mathrm{p}=0.011)$ and tumor stage $(\mathrm{p}=0.004)$ in breast

Table 3: Multiple logistic regression model.

\begin{tabular}{lcccc}
\hline & Estimate & Std. Error & t value & $\operatorname{Pr}(>|\mathbf{t}|)$ \\
\hline (Intercept) & -1.187 & 0.4558 & -2.603 & 0.009 \\
CK56 & 0.032 & 0.2460 & 0.131 & 0.896 \\
ER & -0.009 & 0.0452 & -0.207 & 0.836 \\
HER2 & 0.226 & 0.1577 & 1.434 & 0.152 \\
\hline
\end{tabular}

Null Deviance: 170.1; Residual Deviance: 167.8; AIC: 175.8; Degrees of Freedom: 146

The estimate for the regression coefficients show the change in YB-I corresponding to a unit change in the corresponding marker (ER, HER2, CK5/6), conditional on the other markers remaining constant. No significant correlation can be seen between YB-I and one of the other markers. cancer. Although this does not necessarily reflect a causal relationship, it emphasizes the role of YB-1 as predictive marker. In non-small lung cancer and ovarian cancer and by applying polyclonal antibodies, other groups described an apparent link between YB-1 positivity in the nucleus and tumor staging. However, they did not find any correlation between YB-1 positivity and tumor grade in these entities $[3,55,56]$.

A further finding of our study is the highly significant correlation between nuclear YB-1 expression and negativity of the progesterone receptor status $(\mathrm{p}=0.002)$, which has not been described so far. Since YB-1 has been directly linked to intrinsic or acquired resistance to chemotherapy and thus might be responsible for failure of current treatment regimens, these findings implicate an interesting opportunity for the selection of chemotherapy resistant breast cancer patients out of the whole cohort of patients. ER-positive/PR-negative breast cancers are known to respond less well to selective ER modulator (SERM) therapy than ER-positive/PR-positive tumors [57]. Therefore YB-1 expressing breast cancer may have a general tendency to be hormone refractory, their relative neoplastic potential thus requiring chemotherapy, even if the tumors are of small size, low grade or estrogen receptor positive. 
Our data are not in line with two reports, where YB-1 is more commonly found in ER negative breast tumors $[6,26]$. One may explain this with differences in antibody detection sensitivity, altered epitopes of YB-1 in the nuclear compartment, with the latter being the more likely reason.

In our stratified univariate analysis the prognostic value of nuclear YB-1 expression became even more pronounced in the clinically important subgroup of stage pT1/T2 tumors and breast tumors with negative progesterone receptor status, respectively. Routine mammography screening for breast cancer in women aged 51-70 is becoming a standard in the European Community. Thus, the number and frequency of small sized stage pT1/T2 breast tumors detected is steadily increasing. A YB-1 immunohistochemistry-based diagnostic test could help to identify young patients with small tumors but significant risk of relapse. We are confident that this novel monoclonal YB-1 antibody is of great value in performing prospective studies to establish YB-1 as a tumor marker in the management of human breast cancer. For this purpose large confirmative meta-analyses on independent breast cancer cohorts will be necessary. Therefore we would like to encourage other academic groups to validate our data on their own tumor collections.

\section{Conclusion}

The newly established monoclonal anti-YB-1 antibody (clone F-E2G5) is suited to detect nuclear YB-1 expression and may be of great value for prospective studies to validate YB-1 as a prognostic marker and to adjust treatment in breast cancer patients.

\section{Abbreviations}

AKT: protein kinase B; EGF: epidermal growth factor; ELISA: enzyme-linked immunosorbant assay; ER: estrogen receptor; GFP: green fluorescent protein; Mab: monoclonal antibody; PR: progesterone receptor; YB-1: Y-box binding protein-1.

\section{Competing interests}

PRM is co-founder of antibodies-online and filed a patent relating to monoclonal anti-YB-1 antibody clone F-E2G5. The other authors declare that there are no competing financial or non-financial interests.

\section{Authors' contributions}

ED and PRM designed the study, performed data analyses and drafted the manuscript, AE and RK carried out monoclonal antibody generation and immunoassays, FW and EB were involved in scoring of the tissue array and data interpretation, TF performed statistical analyses and was involved in drafting of the manuscript, PJW and AH were involved in tissue array collection, design and data inter- pretation, SD was involved in data interpretation and drafting of the manuscript, UK participated in the design of the study. PRM originally conceived the study. All authors read and approved the final manuscript.

\section{Acknowledgements}

We are grateful to Ellen Krott for performing the immunohistochemistry. The study has been funded by grants from the Deutsche Forschungsgemeinschaft (SFB542 TP AII, C4 and CI2 to P.R.M.).

\section{References}

I. Janz M, Harbeck N, Dettmar P, Berger U, Schmidt A, Jurchott K, Schmitt $M$, Royer HD: Y-box factor YB-I predicts drug resistance and patient outcome in breast cancer independent of clinically relevant tumor biologic factors HER2, UPA and PAI-I. Int J Cancer 2002, 97(3):278-282.

2. Shibahara K, Sugio K, Osaki T, Uchiumi T, Maehara Y, Kohno K, Yasumoto K, Sugimachi K, Kuwano M: Nuclear expression of the $Y$ box binding protein, YB-I, as a novel marker of disease progression in non-small cell lung cancer. Clin Cancer Res 200I, 7(10):3|5I-3I55.

3. Kamura T, Yahata H, Amada S, Ogawa S, Sonoda T, Kobayashi H, Mitsumoto M, Kohno K, Kuwano M, Nakano $\mathrm{H}$ : Is nuclear expression of $Y$ box-binding protein-I a new prognostic factor in ovarian serous adenocarcinoma? Cancer 1999, 85(I I):2450-2454.

4. Gimenez-Bonafe P, Fedoruk MN, Whitmore TG, Akbari M, Ralph JL, Ettinger S, Gleave ME, Nelson CC: YB-I is upregulated during prostate cancer tumor progression and increases P-glycoprotein activity. Prostate 2004, 59(3):337-349.

5. Oda $Y$, Ohishi $Y$, Saito T, Hinoshita E, Uchiumi T, Kinukawa N, Iwamoto $Y$, Kohno K, Kuwano M, Tsuneyoshi M: Nuclear expression of $Y$-box-binding protein-I correlates with P-glycoprotein and topoisomerase II alpha expression, and with poor prognosis in synovial sarcoma. J Pathol 2003, I99(2):25I-258.

6. Habibi G, Leung S, Law JH, Gelmon K, Masoudi H, Turbin D, Pollak $M$, Nielsen TO, Huntsman D, Dunn SE: Re-defining prognostic factors for breast cancer: YB-I is a stronger predictor of relapse and disease specific survival than estrogen receptor or HER-2 across all tumor subtypes. Breast Cancer Res 2008, I 0(5):R86.

7. Bargou RC, Jurchott K, Wagener C, Bergmann S, Metzner S, Bommert K, Mapara MY, Winzer KJ, Dietel M, Doerken B, Royer HD: Nuclear localization and increased levels of transcription factor YB-I in primary human breast cancers are associated with intrinsic MDRI gene expression. Nat Med 1997, 3(4):447-450.

8. Oda Y, Kohashi K, Yamamoto H, Tamiya S, Kohno K, Kuwano M, Iwamoto $Y$, Tajiri T, Taguchi T, Tsuneyoshi M: Different expression profiles of $Y$-box-binding protein- $I$ and multidrug resistance-associated proteins between alveolar and embryonal rhabdomyosarcoma. Cancer Sci 2008, 99(4):726-732.

9. Oda Y, Ohishi Y, Basaki Y, Kobayashi H, Hirakawa T, Wake N, Ono $M$, Nishio K, Kuwano M, Tsuneyoshi M: Prognostic implications of the nuclear localization of $Y$-box-binding protein-I and CXCR4 expression in ovarian cancer: their correlation with activated Akt, LRP/MVP and P-glycoprotein expression. Cancer Sci 2007, 98(7): 1020-1026.

10. Oda Y, Sakamoto A, Shinohara N, Ohga T, Uchiumi T, Kohno K, Tsuneyoshi M, Kuwano M, Iwamoto Y: Nuclear expression of YBI protein correlates with P-glycoprotein expression in human osteosarcoma. Clin Cancer Res 1998, 4(9):2273-2277.

II. Saji H, Toi M, Saji S, Koike M, Kohno K, Kuwano M: Nuclear expression of YB-I protein correlates with P-glycoprotein expression in human breast carcinoma. Cancer Lett 2003, 190(2): $191-197$.

12. Evdokimova $\mathrm{V}$, Ruzanov P, Anglesio MS, Sorokin AV, Ovchinnikov LP, Buckley J, Triche TJ, Sonenberg N, Sorensen PH: Akt-mediated YB-I phosphorylation activates translation of silent mRNA species. Mol Cell Biol 2006, 26(I):277-292.

13. Kohno K, Izumi H, Uchiumi T, Ashizuka M, Kuwano M: The pleiotropic functions of the Y-box-binding protein, YB-I. Bioessays 2003, 25(7):69|-698. 
14. Raffetseder U, Frye B, Rauen T, Jurchott K, Royer HD, Jansen PL, Mertens PR: Splicing factor SRp30c interaction with Y-box protein-I confers nuclear YB-I shuttling and alternative splice site selection. J Biol Chem 2003, 278(20): |824|-|8248.

15. Swamynathan SK, Nambiar A, Guntaka RV: Role of single-stranded DNA regions and $Y$-box proteins in transcriptional regulation of viral and cellular genes. Faseb J I998, I 2(7):5 I5-522.

16. Wolffe AP, Tafuri S, Ranjan M, Familari M: The Y-box factors: a family of nucleic acid binding proteins conserved from Escherichia coli to man. New Biol 1992, 4(4):290-298.

17. Basaki Y, Hosoi F, Oda Y, Fotovati A, Maruyama Y, Oie S, Ono M, Izumi H, Kohno K, Sakai K, Shimoyama T, Nishio K, Kuwano M: Aktdependent nuclear localization of $Y$-box-binding protein I in acquisition of malignant characteristics by human ovarian cancer cells. Oncogene 2007, 26(I 9):2736-2746.

18. En-Nia A, Yilmaz E, Klinge U, Lovett DH, Stefanidis I, Mertens PR: Transcription factor YB-I mediates DNA polymerase alpha gene expression. J Biol Chem 2005, 280(9):7702-77I I

19. Gu C, Oyama T, Osaki T, Kohno K, Yasumoto K: Expression of $\mathbf{Y}$ box-binding protein-I correlates with DNA topoisomerase Ilalpha and proliferating cell nuclear antigen expression in lung cancer. Anticancer Res 200I, 2 I (4A):2357-2362.

20. Jurchott K, Bergmann S, Stein U, Walther W, Janz M, Manni I, Piaggio G, Fietze E, Dietel M, Royer HD: YB-I as a cell cycle-regulated transcription factor facilitating cyclin $A$ and cyclin $B$ I gene expression. J Biol Chem 2003, 278(30):27988-27996.

21. Schittek B, Psenner K, Sauer B, Meier F, Iftner T, Garbe C: The increased expression of $Y$ box-binding protein $I$ in melanoma stimulates proliferation and tumor invasion, antagonizes apoptosis and enhances chemoresistance. Int J Cancer 2007, I 20(10):21 I0-21 I8.

22. Yoshimatsu T, Uramoto H, Oyama T, Yashima Y, Gu C, Morita M, Sugio K, Kohno K, Yasumoto K: Y-box-binding protein- I expression is not correlated with p53 expression but with proliferating cell nuclear antigen expression in non-small cell lung cancer. Anticancer Res 2005, 25(5):3437-3443.

23. Bergmann S, Royer-Pokora B, Fietze $E$, Jurchott $K$, Hildebrandt $B$, Trost D, Leenders F, Claude JC, Theuring F, Bargou R, Dietel M, Royer HD: YB-I provokes breast cancer through the induction of chromosomal instability that emerges from mitotic failure and centrosome amplification. Cancer Res 2005 65(I 0):4078-4087.

24. Berquin IM, Pang B, Dziubinski ML, Scott LM, Chen YQ, Nolan GP, Ethier SP: Y-box-binding protein I confers EGF independence to human mammary epithelial cells. Oncogene 2005, 24(19):3177-3186.

25. Sakura H, Maekawa T, Imamoto F, Yasuda K, Ishii S: Two human genes isolated by a novel method encode DNA-binding proteins containing a common region of homology. Gene 1988 , 73(2):499-507.

26. Wu J, Lee C, Yokom D, jiang H, Cheang MC, Yorida E, Turbin D, Berquin IM, Mertens PR, Iftner T, Gilks CB, Dunn SE: Disruption of the $\mathbf{Y}$-box binding protein-I results in suppression of the epidermal growth factor receptor and HER-2. Cancer Res 2006, 66(9):4872-4879.

27. Sutherland BW, Kucab J, Wu J, Lee C, Cheang MC, Yorida E, Turbin D, Dedhar S, Nelson C, Pollak M, Leighton Grimes H, Miller K, Badve S, Huntsman D, Blake-Gilks C, Chen M, Pallen C], Dunn SE: Akt phosphorylates the Y-box binding protein I at Serl02 located in the cold shock domain and affects the anchorageindependent growth of breast cancer cells. Oncogene 2005 , 24(26): $4281-4292$.

28. Das S, Chattopadhyay R, Bhakat KK, Boldogh I, Kohno K, Prasad R, Wilson SH, Hazra TK: Stimulation of NEIL2-mediated oxidized base excision repair via YB-I interaction during oxidative stress. J Biol Chem 2007, 282(39):28474-28484

29. Evdokimova $\mathrm{V}$, Ovchinnikov LP, Sorensen $\mathrm{PH}$ : Y-box binding protein I: providing a new angle on translational regulation. Cell Cycle 2006, 5(I I): I |43-I |47.

30. Evdokimova V, Ruzanov P, Imataka H, Raught B, Svitkin Y, Ovchinnikov LP, Sonenberg N: The major mRNA-associated protein YB-I is a potent 5' cap-dependent mRNA stabilizer. Embo J 200I, 20(I9):549I-5502.

31. Shiota M, Izumi H, Onitsuka T, Miyamoto N, Kashiwagi E, Kidani A, Yokomizo A, Naito S, Kohno K: Twist promotes tumor cell growth through YB-I expression. Cancer Res 2008, 68(I):98-105.

32. Lo HW, Hsu SC, Xia W, Cao X, Shih JY, Wei Y, Abbruzzese JL, Hortobagyi GN, Hung MC: Epidermal growth factor receptor cooperates with signal transducer and activator of transcription 3 to induce epithelial-mesenchymal transition in cancer cells via up-regulation of TWIST gene expression. Cancer Res 2007. 67(19):9066-9076

33. Stratford AL, Fry CJ, Desilets C, Davies AH, Cho YY, Li Y, Dong Z Berquin IM, Roux PP, Dunn SE: Y-box binding protein-I serine 102 is a downstream target of p90 ribosomal 56 kinase in basal-like breast cancer cells. Breast Cancer Res 2008, I 0(6):R99.

34. To K, Zhao Y, Jiang H, Hu K, Wang M, Wu J, Lee C, Yokom DW, Stratford AL, Klinge U, Mertens PR, Chen CS, Bally M, Yapp D, Dunn SE: The phosphoinositide-dependent kinase-I inhibitor 2 amino-N-[4-[5-(2-phenanthrenyl)-3-(trifluoromethyl)-I Hpyrazol-I-yl]phen $y I]$-acetamide (OSU-030I2) prevents $Y$. box binding protein-I from inducing epidermal growth factor receptor. Mol Pharmacol 2007, 72(3):64I-652.

35. Kuwano $M$, Uchiumi T, Hayakawa $H$, Ono $M$, Wada $M$, Izumi $H$, Kohno K: The basic and clinical implications of $A B C$ transporters, Y-box-binding protein-I (YB-I) and angiogenesisrelated factors in human malignancies. Cancer Sci 2003, 94(I):9-14

36. Fujii T, Kawahara A, Basaki Y, Hattori S, Nakashima K, Nakano K, Shirouzu K, Kohno K, Yanagawa T, Yamana H, Nishio K, Ono M, Kuwano M, Kage M: Expression of HER2 and estrogen receptor alpha depends upon nuclear localization of $\mathbf{Y}$-box binding protein-I in human breast cancers. Cancer Res 2008 68(5): $1504-1512$

37. Coller HA, Coller BS: Statistical analysis of repetitive subcloning by the limiting dilution technique with a view toward ensuring hybridoma monoclonality. Hybridoma 1983 , 2(I):91-96.

38. Bayer EA, Wilchek $M$ : The use of the avidin-biotin complex as a tool in molecular biology. Methods Biochem Anal 1980, 26: |-45.

39. Mertens PR, Harendza S, Pollock AS, Lovett DH: Glomerular mesangial cell-specific transactivation of matrix metalloproteinase 2 transcription is mediated by YB-I. J Biol Chem 1997, 272(36):22905-22912

40. Veeck J, Chorovicer M, Naami A, Breuer E, Zafrakas M, Bektas N, Durst M, Kristiansen G, Wild PJ, Hartmann A, Knuechel R, Dahl E: The extracellular matrix protein ITIH5 is a novel prognostic marker in invasive node-negative breast cancer and its aberrant expression is caused by promoter hypermethylation. Oncogene 2007, 27(6):865-76.

4I. Dahl E, Kristiansen G, Gottlob K, Klaman I, Ebner E, Hinzmann B, Hermann K, Pilarsky C, Durst M, Klinkhammer-Schalke M, Blaszyk H, Knuechel R, Hartmann A, Rosenthal A, Wild PJ: Molecular profiling of laser-microdissected matched tumor and normal breast tissue identifies karyopherin alpha2 as a potential novel prognostic marker in breast cancer. Clin Cancer Res 2006, I 2(13):3950-3960.

42. Remmele W, Stegner HE: [Recommendation for uniform definition of an immunoreactive score (IRS) for immunohistochemical estrogen receptor detection (ER-ICA) in breast cancer tissue]. Pathologe |987, 8(3): | 38- | 40.

43. van Roeyen CR, Eitner F, Martinkus S, Thieltges SR, Ostendorf T, Bokemeyer D, Luscher B, Luscher-Firzlaff JM, Floege J, Mertens PR: Y-box protein I mediates PDGF-B effects in mesangioproliferative glomerular disease. I Am Soc Nephrol 2005 I 6( I 0):2985-2996

44. Perou CM, Sorlie T, Eisen MB, Rijn M van de, Jeffrey SS, Rees CA, Pollack JR, Ross DT, Johnsen H, Akslen LA, Fluge O, Pergamenschikov A Williams C, Zhu SX, Lønning PE, Børresen-Dale AL, Brown PO, Botstein D: Molecular portraits of human breast tumours. Nature 2000, 406(6797):747-752

45. Sorlie T, Perou CM, Tibshirani R, Aas T, Geisler S, Johnsen H, Hastie T, Eisen MB, Rijn M van de, Jeffrey SS, Thorsen T, Quist H, Matese JC, Brown PO, Botstein D, Eystein Lønning P, Børresen-Dale AL: Gene expression patterns of breast carcinomas distinguish tumor subclasses with clinical implications. Proc Natl Acad Sci USA 200।, 98(I 9): I0869-10874.

46. Fogt F, Poremba C, Shibao K, Itoh H, Kohno K, Zimmerman RL, Gortz HG, Dockhorn-Dworniczak B, Urbanski SJ, Alsaigh N, Heinz D, Noffsinger AE, Shroyer KR: Expression of survivin, YB-I, and KI- 
67 in sporadic adenomas and dysplasia-associated lesions or masses in ulcerative colitis. Appl Immunohistochem Mol Morphol 2001, 9(2): |43-149.

47. Fujita $T$, Ito $K$, Izumi $H$, Kimura $M$, Sano $M$, Nakagomi $H$, Maeno $K$, Hama $Y$, Shingu K, Tsuchiya S, Kohno K, Fujimori M: Increased nuclear localization of transcription factor $Y$-box binding protein I accompanied by up-regulation of $\mathbf{P}$-glycoprotein in breast cancer pretreated with paclitaxel. Clin Cancer Res 2005, I I(24 Pt I):8837-8844.

48. Huang J, Tan PH, Li KB, Matsumoto K, Tsujimoto M, Bay BH: Y-box binding protein, YB-I, as a marker of tumor aggressiveness and response to adjuvant chemotherapy in breast cancer. Int J Oncol 2005, 26(3):607-613.

49. Huang $X$, Ushijima K, Komai K, Takemoto Y, Motoshima S, Kamura $\mathrm{T}$, Kohno K: Co-expression of $\mathbf{Y}$ box-binding protein-I and $\mathbf{P}$ glycoprotein as a prognostic marker for survival in epithelial ovarian cancer. Gynecol Oncol 2004, 93(2):287-29l.

50. Stratford AL, Habibi G, Astanehe A, Jiang H, Hu K, Park E, Shadeo A, Buys TP, Lam W, Pugh T, Marra M, Nielsen TO, Klinge U, Mertens PR, Aparicio S, Dunn SE: Epidermal growth factor receptor (EGFR) is transcriptionally induced by the Y-box binding protein-I (YB-I) and can be inhibited with Iressa in basal-like breast cancer, providing a potential target for therapy. Breast Cancer Res 2007, 9(5):R6I.

51. Lu ZH, Books JT, Ley TJ: Cold shock domain family members YB-I and MSY4 share essential functions during murine embryogenesis. Mol Cell Biol 2006, 26(22):84I 0-84I7.

52. Sorokin AV, Selyutina AA, Skabkin MA, Guryanov SG, Nazimov IV, Richard C, Th'ng J, Yau J, Sorensen PH, Ovchinnikov LP, Evdokimova $\mathrm{V}$ : Proteasome-mediated cleavage of the $\mathbf{Y}$-box-binding protein I is linked to DNA-damage stress response. Embo j 2005, 24(20):3602-36I2.

53. Stenina OI, Poptic EJ, DiCorleto PE: Thrombin activates a $\mathbf{Y}$ boxbinding protein (DNA-binding protein B) in endothelial cells. J Clin Invest 2000, I06(4):579-587.

54. Abba MC, Drake JA, Hawkins KA, Hu Y, Sun H, Notcovich C, Gaddis S, Sahin A, Baggerly K, Aldaz CM: Transcriptomic changes in human breast cancer progression as determined by serial analysis of gene expression. Breast Cancer Res 2004, 6(5):R499-5I3.

55. Gessner C, Woischwill C, Schumacher A, Liebers U, Kuhn H, Stiehl P, Jurchott K, Royer HD, Witt C, Wolff G: Nuclear YB-I expression as a negative prognostic marker in nonsmall cell lung cancer. Eur Respir J 2004, 23(I): I4-19.

56. Yahata $\mathrm{H}$, Kobayashi H, Kamura T, Amada S, Hirakawa T, Kohno K, Kuwano M, Nakano H: Increased nuclear localization of transcription factor $\mathrm{YB}-\mathrm{I}$ in acquired cisplatin-resistant ovarian cancer. J Cancer Res Clin Oncol 2002, I 28(I I):62 I-626.

57. Cui X, Schiff R, Arpino G, Osborne CK, Lee AV: Biology of progesterone receptor loss in breast cancer and its implications for endocrine therapy. J Clin Oncol 2005, 23(30):772I-7735.

\section{Pre-publication history}

The pre-publication history for this paper can be accessed here:

http://www.biomedcentral.com/1471-2407/9/410/pre pub

\section{Publish with Biomed Central and every scientist can read your work free of charge}

"BioMed Central will be the most significant development for disseminating the results of biomedical research in our lifetime. "

Sir Paul Nurse, Cancer Research UK

Your research papers will be:

- available free of charge to the entire biomedical community

- peer reviewed and published immediately upon acceptance

- cited in PubMed and archived on PubMed Central

- yours - you keep the copyright

Submit your manuscript here:

http://www.biomedcentral.com/info/publishing_adv.asp
BiolMedcentral 